\title{
The Management of Urine Storage Dysfunction in the Neurological Patient
}

\author{
Ulrich Mehnert ${ }^{1}$ (1) - Emmanuel Chartier-Kastler ${ }^{2}$ - Stefan de Wachter ${ }^{3}$ - Philip E.V.A. van Kerrebroeck ${ }^{4}$ \\ Gommert A. van Koeveringe ${ }^{4}$
}

Accepted: 13 September 2018 / Published online: 5 December 2018

(C) The Author(s) 2018

\begin{abstract}
To highlight the current aspects and developments in the management of neurogenic urine storage dysfunction and to sensitize urologists for this interdisciplinary and important topic. Neurogenic lower urinary tract dysfunction affects a large proportion of patients with chronic neurological diseases or lesions such as multiple sclerosis, Parkinson's disease, stroke, spina bifida, and spinal cord injury. Such a dysfunction is not only highly bothersome and devastating for the quality of life but also poses a significant risk for health. Particularly, detrusor overactivity and detrusor-sphincterdyssynergia are frequent pathological patterns in neurogenic lower urinary tract dysfunction that are associated with sequelae such as recurrent urinary tract infections and renal impairment. The current cornerstones of treatment for urine storage dysfunction in neurological patients such as intermittent self-catheterization, antimuscarinic drugs, botulinum neurotoxin A intradetrusor injections, augmentation cystoplasty, urinary diversion, and artificial urinary sphincter have significantly contributed to improvements in QoL, health, and survival of neurological patients affected by neurogenic lower urinary tract dysfunction. However, these treatments have not advanced much recently. Moreover, the level of evidence of many therapy options specifically regarding their application in neurological patients is quite low and the main and auxiliary mechanisms of action are often only poorly understood. Despite former accomplishments in NeuroUrology, more specific evidence for treatments of lower urinary tract dysfunction in neurological patients as well as better knowledge on their mechanisms of action is needed to advance the field and exploit the full treatment potential of available therapies.
\end{abstract}

Keywords Neurogenic bladder disorder $\cdot$ Urinary incontinence $\cdot$ Antimuscarinics $\cdot$ Neuromodulation $\cdot$ Botulinum neurotoxin A . Urinary diversion

This article is part of the Topical Collection on Surgery

Ulrich Mehnert

ulrich.mehnert@balgrist.ch

1 Department of Neuro-Urology, Balgrist University Hospital, University of Zürich, Forchstrasse 340, 8008 Zürich, Switzerland

2 Department of Urology, Pitié-Salpêtrière University Hospital, Assistance Publique-Hôpitaux de Paris, Pierre et Marie Curie Medical School, Sorbonne Université, Paris, France

3 Department of Urology, Antwerp University Hospital and Faculty of Medicine, University of Antwerp, Antwerp, Belgium

4 Department of Urology, Maastricht University Medical Center, University of Maastricht, Maastricht, the Netherlands

\section{Introduction}

The human lower urinary tract (LUT), comprising the urinary bladder, the urethra, and the external urethral sphincter, has two opposing functions [1]: (1) the low pressure, continent, and symptom free storage of urine which is constantly draining from the kidneys, and (2) the periodical, voluntarily controlled, unobstructed, and complete release of the stored urine.

The correct progression of each phase and specifically the switch from one phase to the other requires the orchestration of a neural network of afferent and efferent pathways involving different levels of the nervous system, i.e., peripheral autonomic and somatic nerves, spinal neurons and tracts, and finally supraspinal processes to enable voluntary control and judgment of appropriateness (Fig. 1). 


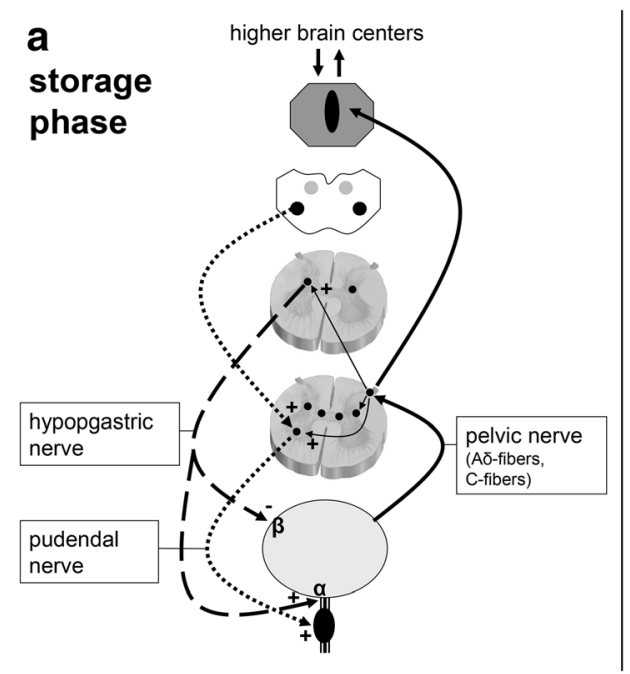

Fig. 1 Schematic illustration of spinal cord and brain stem regions involved in lower urinary tract (LUT) control and their most relevant neuronal connection to the LUT. The illustration summarizes the findings of neurophysiological animal studies from De Groat et al. [2] and early functional neuroimaging studies in humans from Blok et al. [3]. During the storage phase (a), which normally accounts for most of the day $(98 \%)$, the detrusor is relaxed and the bladder neck closed due to sympathetic tone acting on the bladder body and neck. Sympathetic fibers travel along the hypogastric nerve from the sympathetic nuclei in the intermediolateral column of the lumbar spinal cord to the LUT and provide adrenergic input to beta-receptors on intramural ganglia of the bladder body ( $\rightarrow$ relaxation) and alpha-receptors at the bladder neck $(\rightarrow$ contraction/closure). Bladder afferents traverse through the pelvic nerve and enter the dorsal horn of the sacral spinal cord. At low filling volumes, there might be only little afferent activity and weak afferent signals might reach the PAG and diencephalic structures (e.g., thalamus), but bladder sensations do usually not reach consciousness during this state. With increasing bladder volumes, afferent activity might increase, likely due to changes in intravesical pressure and at some degree of filling, bladder sensations will reach consciousness in the form of a first desire to void. From the sacral dorsal horn, excitatory collaterals reach the sympathetic nuclei in the lumbar intermediolateral column and the sacral frontal horn, where the motor neurons of the external urethral sphincter (EUS) are located (Onuf's nucleus), to facilitate sympathetic input to the bladder and bladder neck, and somatic input to the EUS respectively. This supports continence during increasing bladder volumes, when voiding has to be postponed. Another region thought to be responsible for continence is the pontine L-region (named L-region as it is lateral to the other relevant pontine structure named the pontine micturition center or M-region or Barrington's nucleus), which has excitatory input to the EUS motor neurons in Onuf's nucleus and thus facilitates the elevation of the EUS tone. If the decision to empty the bladder is made (in the higher brain centers), the periaqueductal gray (PAG) activates the pontine micturition centre (PMC) (b). The switch between L-region and PMC activation is sometimes conceived in a simplified manner as moving a lever from one programme to the other. Only one region can be activated at a time. From the PMC strong inhibitory inputs reach the sympathetic nuclei in the intermediolateral lumbar cord to suppress the sympathetic input to bladder body and bladder neck to enable synergic micturition. Simultaneously, the PMC has strong excitatory projections to the parasympathetic nuclei in the sacral spinal cord that in turn activate the detrusor muscle via muscarinic receptors. The parasympathetic fibers travel along the pelvic nerve. In addition to the parasympathetic activation, the PMC has excitatory collaterals to inhibitory interneurons in the sacral cord that reduce the activity of EUS motor neurons, and thus facilitate EUS relaxation and synergic micturition. Figure and legend reprinted by permission from Springer-Verlag London Limited: Mehnert [4]
Hence, it is not surprising that neurological diseases or lesions that interfere with such complex neuronal control easily lead to dysfunction and/or symptoms in the LUT. Indeed, the prevalence of lower urinary tract dysfunction (LUTD) and related symptoms in neurological conditions such as spinal cord injury (SCI), multiple sclerosis (MS), Parkinson's disease (PD), and stroke, can reach $100 \%$ (Tables 1 and 2).

Lower urinary tract symptoms (LUTS) such as urinary frequency, urgency, and incontinence or urinary retention are highly bothersome $[15,16]$ and severely reduce quality of life (QoL) [17] particularly in neurological patients as they often already struggle with the comorbidities of their neurological disease / lesion such as impaired mobility. Hence, restoration of bladder function is one of the top priorities of individuals with neurogenic lower urinary tract dysfunction (NLUTD), such as SCI patients [18].

In addition, the underlying dysfunction of LUTS (Tables 3 and 4) can bear certain health risks. The most relevant sequelae that are associated with NLUTD are upper urinary tract (UUT) damage, i.e., impairment of kidney function, and recurrent urinary tract infections [20-28].

Not by accident, renal disease and other urological complications such as urosepsis ranged among the most frequent causes of death in SCI patients until the mid 1970s whereupon neuro-urological work up and follow-up gradually became 
Table 1 Prevalence of different neurogenic lower urinary tract dysfunction (NLUTD) and symptoms in multiple sclerosis (MS), Parkinson's disease (PD), multiple system atrophy (MSA), and stroke. Table adapted from [5]

\begin{tabular}{|c|c|c|c|c|}
\hline & MS & $\mathrm{PD}$ & MSA & Stroke \\
\hline Prevalence of NLUTD & $34-99 \%[6]$ & $27-71 \%[7,8]$ & $78-96 \%[9]$ & $38-94 \%[10,11]$ \\
\hline $\begin{array}{l}\text { Average time interval between diagnosis } \\
\text { of neurological disease and onset of } \\
\text { urological symptoms [years] }\end{array}$ & $5.9(4.6-7.8)[6]$ & $5[12]$ & $2[12]$ & \\
\hline Urinary urgency & $63.4 \%(32-86 \%)[6]$ & $33-68 \%[7,8]$ & $63 \%[13]$ & $70 \%[10]$ \\
\hline Urinary frequency & $54.4 \%(25-99 \%)[6]$ & $16-71 \%[7,8]$ & $45 \%[13]$ & $59 \%[10]$ \\
\hline Nocturia & & $60-86 \%[7,8]$ & $74 \%[13]$ & $76 \%[10]$ \\
\hline Urinary urgency incontinence & $56.3 \%(19-80 \%)[6]$ & $27 \%[8]$ & $63 \%[13]$ & $29 \%[10]$ \\
\hline Dysuria & $34.8 \%(6-79.5 \%)[6]$ & $30 \%[12]$ & $69 \%[12]$ & $6 \%[10]$ \\
\hline $\begin{array}{l}\text { Retention / incomplete bladder } \\
\text { emptying } \\
(\text { PVRV }>100 \mathrm{~mL})\end{array}$ & $\begin{array}{l}35.6 \%(8.3-73.8 \%) \\
\quad[6]\end{array}$ & & $52 \%[13]$ & $48 \%[10]$ \\
\hline DO & $65 \%(43-99 \%)[6]$ & $45-93 \%[8]$ & $35-56 \%[12,13]$ & $36-82 \%[10]$ \\
\hline DSD & $35 \%(5-83 \%)[6]$ & & $47-98 \%$ (incl. bladder neck dyssynergia) $[12,13]$ & \\
\hline Reduced compliance & $2-10 \%[6]$ & & $31 \%[13]$ & \\
\hline Detrusor hypocontractility & $25 \%(0-40 \%)[6]$ & $53 \%[8]$ & $52-67 \%[9,12]$ & $33-40 \%[10]$ \\
\hline $\begin{array}{l}\text { Open bladder neck during filling } \\
\text { cystometry }\end{array}$ & & $31 \%[9]$ & $87 \%[9]$ & \\
\hline Pathologic EUS-EMG & & $5 \%[9]$ & $93 \%[9]$ & \\
\hline
\end{tabular}

The listed numbers reflect only gross guide values due to sparse and/or heterogeneous data form investigations using different assessment methods. $P V R V$ post void residual volume, $D O$ detrusor overactivity, $D S D$ detrusor-sphincter-dyssynergia, $E U S-E M G$ external urethral sphincter electromyogram

established [29-36]. Nowadays, due to improvements in medical care, including neuro-urological management, many patients with neurological disease or trauma and NLUTD have increased their life expectancy to a level close to normal [33, 37-40]. As a consequence, not only the number of elderly individuals with NLUTD is increasing but also the time period for which they have to deal with their NLUTD. This is further potentiated by the increasing life expectancy of the general population, and consequently, age-associated, chronic degenerative neurological diseases such as PD [41, 42]. Finally, these aspects are also relevant from a uro-oncological view point as, while the incidence of bladder malignancies may not be necessarily higher in NLUTD compared to the general population, they may occur earlier and with a more rapid/aggressive progression. This can, in conjunction with the comorbidities related to the neurological disease/lesion, lead to a higher degree of morbidity [43-45]. Thus, it is all the more important to understand how to manage NLUTD and associated complications to provide sustainable treatment and follow-up strategies.

\section{Storage Dysfunction of the Lower Urinary Tract in Neurological Patients}

\section{Detrusor Overactivity}

One of the most relevant risk factors for developing LUTS and complications of lower and upper urinary tract, especially in neurological patients, is detrusor overactivity (DO) $[21,28$, 46-48]. This term describes a condition of involuntary detrusor contractions during the storage phase that result from loss or impaired supraspinal inhibitory input to the sacral bladder reflex circuitry. This also implicates that DO can occur as a consequence of any lesion / disease affecting the suprasacral central nervous system. This makes DO one of the most common dysfunctions in neurological patients (Tables 1 and 2). DO can be visualized and diagnosed using filling cystometry. This specialized examination provides details on the maximum pressure amplitude during DO, the frequency and duration of DO, and the volume of DO occurrence, which are relevant parameters for a full understanding and characterization of the extent of DO. An increase in detrusor pressure during DO will usually cause a sensation of urgency, if sensory function is maintained. When pressure levels of DO exceed the sub-vesical closing pressure, the DO will result in DO incontinence. Moreover, DO has been proven to be associated with irreversible morphological alterations of the LUT and renal function impairment in the long-term [20-23, 25, 26].

The morphological alterations associated with DO include detrusor hypertrophy, trabeculation of the bladder wall, and the development of pseudo-diverticula [25]. Renal function impairment associated with DO may occur through multiple mechanisms, such as obstruction, excessive pressure exposure, and recurrent infections.

Usually, the terminal distal parts of the ureters pass transversely through the bladder wall to their orifices in the trigone 
Table 2 Associations between injury levels and urodynamic findings in patients with spinal cord injury (SCI) based on a meta-analysis by Jeong et al. [14]

\begin{tabular}{|c|c|c|c|c|c|}
\hline \multicolumn{5}{|l|}{ Level of SCI } & \multirow[t]{2}{*}{$p$ value } \\
\hline & Cervical & Thoracic & Lumbar & Sacral & \\
\hline No. of Patients & 259 & 215 & 137 & 46 & \\
\hline DO [\%] & 65 & 78 & 49 & 22 & $<0.001$ \\
\hline DSD [\%] & 63 & 72 & 33 & 13 & $<0.001$ \\
\hline DU [\%] & 9 & 9 & 39 & 70 & $<0.001$ \\
\hline Normal [\%] & 1 & 2 & 2 & 9 & 0.002 \\
\hline
\end{tabular}

Thoracic lesions are indicated to spinal cord level T9 or above, and injuries at the T10 through T12 levels are included in lumbar lesions. The combined suprasacral and sacral lesions have been excluded from this analysis

$D O$ detrusor overactivity. $D S D$ detrusor-sphincter-dyssynergia. $D U$ detrusor underactivity. Table adapted from [14]

*Pearson chi-square test

[49]. This intramural passage provides a flap valve mechanism with compression of the intramural ureter parts during a detrusor contraction, preventing vesico-ureteral reflux (VUR) during micturition. During storage, when the detrusor is relaxed, the intramural ureter is not compressed and can thus deliver the urine into the bladder. However, in case of detrusor hypertrophy due to chronic DO, the intramural ureter parts may become constantly compressed by the hypertrophic detrusor resulting in ureteric outflow obstruction, which in the long-term will lead to dilatation of the ureters and subsequently also of the pelvicalyceal system of the kidneys [25]. Such pressure-related ectasia of the UUT is associated with renal damage [25, 27].

Even prior to the development of detrusor hypertrophy, DO can become harmful to renal function if detrusor pressure increases to amplitudes above $40 \mathrm{cmH} 2 \mathrm{O}$, pressures that have been demonstrated to be associated with UUT deterioration [21, 22, 50, 51]. However, this pressure threshold of $40 \mathrm{cmH} 2 \mathrm{O}$ for UUT damage is deemed controversial due to the rather low level of evidence and the clinical observation that intravesical storage pressures below $40 \mathrm{cmH} 2 \mathrm{O}$ do not guarantee UUT safety but may result in even more severe UUT deterioration if tolerated over a longer period of time. Hence, the pressure level of DO alone is certainly not the only factor related to UUT deterioration but rather a mixture of pressure level, frequency of DO contractions, and duration of pressure elevation during single DO contractions [52]. Development of VUR in this context may aggravate pressure exposure and transmission to the kidneys but the absence of VUR does not prevent renal impairment in DO.

UUT deterioration due to DO may even be accelerated by recurrent urinary tract infections (UTI). Patients with LUTD such as DO are prone to develop recurrent UTI [24, 47, 53] and in conditions of altered UUT urodynamics, i.e., obstruction and VUR, such infections may reach the upper urinary tract more frequently and easily.

\section{Detrusor-Sphincter-Dyssynergia}

The development of elevated storage pressures and dysfunctional dynamics of the urinary tract due to DO may aggravate with Detrusor-Sphincter-Dyssynergia (DSD), which is frequently associated with DO specifically in neurological patients [54].

DSD is defined as a detrusor contraction concurrent with an involuntary contraction of the urethral sphincter and/or periurethral striated muscle groups. Occasionally, flow may be prevented altogether [55]. Hence, DSD may on the symptomatic level limit or prevent urinary incontinence but in turn contribute to significant rise of intravesical pressure due to functional subvesical outlet obstruction during a detrusor contraction. Such DSD-related intravesical pressure excesses can increase urgency or pain symptoms and, more importantly, potentiate the risks for LUT and UUT complications, the latter leading to significant renal damage in the long run [56].

Different types of DSD have been described previously [57-59]: type (1) concomitant increase in both detrusor pressure and sphincter EMG activity with sudden sphincter relaxation at the peak of the detrusor contraction, type (2) sporadic contractions of the external urethral sphincter throughout the detrusor contraction, and type (3) a crescendo-decrescendo pattern of sphincter contraction which results in urethral obstruction throughout the entire detrusor contraction. However, the clinical relevance of the different types of DSD is controversial as type distinction does not yet have any impact on treatment decision or outcome $[59,60]$.

\section{Autonomic Dysreflexia}

An acute and potentially life-threatening complication associated with DO/DSD most commonly observed in SCI patients with lesions above the thoracic (Th) level 6 is autonomic dysreflexia (AD) $[61,62]$. AD is defined as an increase in systolic blood pressure (SBP) of at least $20 \mathrm{mmHg}$ from baseline [63]. It is based on an sympathetic overreaction due to the loss of descending central (brain stem) inhibitory pathways to the sympathetic chain causing vasoconstriction below the level of lesion and consequently a blood pressure increase [61]. This becomes especially pertinent in SCI lesions above Th6 due to the lack of central modulation on the splanchnic nerves that usually emanate below Th5 but innervate the critical mass of blood vessels required to cause elevation of the blood pressure [61]. In response to the excessive hypertension during AD, baroreceptors above the lesion level may become activated and induce a vagal-mediated bradycardia. This compensatory parasympathetic output above the level of lesion is thought to be responsible also for symptoms such as 
Table 3 Summary of common storage symptoms that might occur due to lower urinary tract dysfunction in neurological diseases or lesions in association with their typically related urodynamic and clinical findings.
Definitions of Symptoms are reproduced from the International Continence Society Standardisation of terminology in lower urinary tract function [19]

\begin{tabular}{|c|c|c|}
\hline Storage symptom & $\begin{array}{l}\text { Most typical urodynamic and clinical findings } \\
\text { (listed are single findings that can also occur in combination) }\end{array}$ & $\begin{array}{l}\text { Typical neurological } \\
\text { lesion site }\end{array}$ \\
\hline Urinary urgency & - Detrusor overactivity ${ }^{1,2}$ & 1 suprasacral \\
\hline $\begin{array}{l}\text { Complaint of a sudden compelling desire to pass } \\
\text { urine which is difficult to defer. }\end{array}$ & - Low bladder compliance ${ }^{1,2}$ & 2 supraspinal \\
\hline $\begin{array}{l}\text { Urinary frequency (increased daytime frequency, } \\
\text { pollakisuria) }\end{array}$ & $\begin{array}{l}\text { - Detrusor overactivity }{ }^{1,2} \\
\text { - Low bladder compliance } \\
1,2\end{array}$ & $\begin{array}{l}1 \text { suprasacral } \\
2 \text { supraspinal }\end{array}$ \\
\hline $\begin{array}{l}\text { Complaint by the patient who considers that } \\
\text { he/she voids too often by day. }\end{array}$ & $\begin{array}{l}\text { - Incomplete bladder emptying / elevated post void } \\
\text { residual volume due to hypocontractile detrusor }{ }^{3,4} \\
\text { or bladder outlet obstruction } \\
\text { (anatomical: prostate enlargement, urethral stricture; } \\
\text { functional: detrusor-sphincter-dyssynergia }{ }^{1,2} \text { ) }\end{array}$ & $\begin{array}{l}3 \text { subsacral / lumbosacral } \\
4 \text { peripheral }\end{array}$ \\
\hline Nocturia & - Detrusor overactivity ${ }^{1,2}$ & 1 suprasacral \\
\hline $\begin{array}{l}\text { Complaint that the individual has to wake at } \\
\text { night one or more times to void. }\end{array}$ & $\begin{array}{l}\text { - Low bladder compliance }{ }^{1,2} \\
\text { - Incomplete bladder emptying / elevated post void } \\
\text { residual volume due to hypocontractile detrusor }{ }^{3,4} \text { or } \\
\text { bladder outlet obstruction (anatomical: prostate enlargement, } \\
\text { urethral stricture; functional: detrusor-sphincter-dyssynergia }{ }^{1,2} \text { ) }\end{array}$ & $\begin{array}{l}2 \text { supraspinal } \\
3 \text { subsacral / lumbosacral } \\
4 \text { peripheral }\end{array}$ \\
\hline Urgency urinary incontinence & - Detrusor overactivity ${ }^{1,2}$ & 1 suprasacral \\
\hline $\begin{array}{l}\text { Complaint of involuntary leakage accompanied } \\
\text { by or immediately preceded by urgency. }\end{array}$ & - Low bladder compliance ${ }^{1,2}$ & 2 supraspinal \\
\hline Stress urinary incontinence & - Urethral sphincter insufficiency ${ }^{3,4}$ & 3 subsacral / lumbosacral \\
\hline $\begin{array}{l}\text { Complaint of involuntary leakage on effort or } \\
\text { exertion, or on sneezing or coughing. }\end{array}$ & - Bladder neck incompetence ${ }^{3,4}$ & 4 peripheral \\
\hline Mixed urinary incontinence & - Detrusor overactivity ${ }^{1,2}$ & 1 suprasacral \\
\hline $\begin{array}{l}\text { Complaint of involuntary leakage associated } \\
\text { with urgency and also with exertion, effort, } \\
\text { sneezing or coughing. }\end{array}$ & $\begin{array}{l}\text { - Low bladder compliance }{ }^{1,2} \\
\text { AND } \\
\text { - Urethral sphincter insufficiency } 3,4 \\
\text { - Bladder neck incompetence } \\
\text { 3,4 }\end{array}$ & $\begin{array}{l}2 \text { supraspinal } \\
3 \text { subsacral / lumbosacral } \\
4 \text { peripheral }\end{array}$ \\
\hline Continuous urinary incontinence & - Open bladder neck and flaccid urethral sphincter ${ }^{3,4}$ & 1 suprasacral \\
\hline Complaint of continuous urinary leakage. & $\begin{array}{l}\text { OR } \\
\text { - Overflow incontinence due to bladder outlet obstruction } \\
\text { (anatomical: prostate enlargement, urethral stricture; } \\
\text { functional: detrusor-sphincter-dyssynergia }{ }^{1,2} \text { ) } \\
\text { and/or acontractile }{ }^{3,4} \text {, hyposensitive bladder }{ }^{3,4}\end{array}$ & $\begin{array}{l}2 \text { supraspinal } \\
3 \text { subsacral / lumbosacral } \\
4 \text { peripheral }\end{array}$ \\
\hline $\begin{array}{l}\text { Reduced or absent bladder sensation } \\
\text { The individual is aware of bladder filling but does } \\
\text { not feel a definite desire to void or reports no } \\
\text { sensation of bladder filling or desire to void. }\end{array}$ & $\begin{array}{l}\text { - Bladder distension during filling cystometry is not } \\
\text { perceived or only at high volumes }{ }_{1-4}\end{array}$ & $\begin{array}{l}1 \text { suprasacral (only in } \\
\text { complete spinal cord } \\
\text { lesions) } \\
2 \text { supraspinal (only in } \\
\text { complete spinal cord } \\
\text { lesions) } \\
3 \text { subsacral / lumbosacral } \\
4 \text { peripheral }\end{array}$ \\
\hline $\begin{array}{l}\text { Increased bladder sensation } \\
\text { The individual feels an early and persistent } \\
\quad \text { desire to void. }\end{array}$ & $\begin{array}{l}\text { - Bladder distension during filling cystometry is } \\
\text { perceived early, at low volumes } 1,2 \text {. }\end{array}$ & $\begin{array}{l}1 \text { suprasacral } \\
2 \text { supraspinal }\end{array}$ \\
\hline
\end{tabular}

headache, flushing and sweating in the head and neck region [61]. However, AD may also occur completely asymptomatically, which makes it even more hazardous in daily life.

In addition to $\mathrm{DO} / \mathrm{DSD}, \mathrm{AD}$ can be triggered by various, often usually benign stimuli below the lesion, i.e., bladder and/or bowel distention, urinary stones or infection, skin lesions/irritations, wounds, fractures, menstruation, and sexual intercourse [64]. When AD occurs, it is important and most effective to eliminate the trigger stimulus, i.e. emptying the bladder, to prevent otherwise rapid progression of $\mathrm{AD}$.

\section{Restoration of Urinary Bladder Storage Function}

DO with or without DSD are the main causes of increased storage pressures and long-term damage to the UUT and LUT particularly in neurological patients [20-24, 26-28, 46, $47,50]$. Hence, to protect the UUT function and prevent longterm complications, it is necessary to maintain or restore lowpressure and unrestricted urinary drainage from the kidneys [65]. Depending upon to the extend and severity of the 
Table 4 Summary of common voiding symptoms that might occur due to lower urinary tract dysfunction in neurological diseases or lesions in association with their typically related urodynamic and clinical findings.
Definitions of Symptoms are reproduced from the International Continence Society Standardisation of terminology in lower urinary tract function [19]

\begin{tabular}{|c|c|c|}
\hline Voiding symptom & $\begin{array}{l}\text { Most typical urodynamic and clinical findings } \\
\text { (listed are single findings that can also } \\
\text { occur in combination) }\end{array}$ & $\begin{array}{l}\text { Typical neurological } \\
\text { lesion site }\end{array}$ \\
\hline $\begin{array}{l}\text { Urinary retention } \\
\text { Inability to pass urine to empty the bladder. This might } \\
\quad \text { occur acute or chronically, complete or incomplete. }\end{array}$ & $\begin{array}{l}\text { - Hypo- or acontractile detrusor muscle } \\
\text { - Bladder outlet obstruction (anatomical: } \\
\text { prostate enlargement; functional: } \\
\text { detrusor-sphincter-dyssynergia }^{1,2} \text { ) }\end{array}$ & $\begin{array}{c}1 \text { suprasacral } \\
2 \text { supraspinal } \\
3 \text { subsacral / } \\
\text { lumbosacral } \\
4 \text { peripheral }\end{array}$ \\
\hline $\begin{array}{l}\text { Urinary hesitancy } \\
\text { An individual describes difficulty in initiating micturition } \\
\text { resulting in a delay in the onset of voiding after the } \\
\text { individual is ready to pass urine. }\end{array}$ & $\begin{array}{l}\text { - Bladder outlet obstruction (anatomical: prostate } \\
\text { enlargement, urethral stricture; functional: } \\
\text { detrusor-sphincter-dyssynergia }{ }^{1,2} \text { ) } \\
\text { - Hypocontractile detrusor } 3,4\end{array}$ & $\begin{array}{l}1 \text { suprasacral } \\
2 \text { supraspinal } \\
3 \text { subsacral / } \\
\text { lumbosacral } \\
4 \text { peripheral }\end{array}$ \\
\hline $\begin{array}{l}\text { Urinary intermittency } \\
\text { An individual describes urine flow which stops } \\
\quad \text { and starts, on one or more occasions, during micturition. }\end{array}$ & $\begin{array}{l}\text { - Detrusor-sphincter-dyssynergia }{ }^{1,2} \\
\text { - Hypocontractile detrusor } 3,4\end{array}$ & $\begin{array}{l}1 \text { suprasacral } \\
2 \text { supraspinal } \\
3 \text { subsacral / } \\
\text { lumbosacral } \\
4 \text { peripheral }\end{array}$ \\
\hline $\begin{array}{l}\text { Slow urinary stream } \\
\text { Perception of reduced urine flow, usually compared to previous } \\
\quad \text { performance or in comparison to others. }\end{array}$ & $\begin{array}{l}\text { - Bladder outlet obstruction (anatomical: prostate } \\
\text { enlargement, urethral stricture; functional: } \\
\text { detrusor-sphincter-dyssynergia }{ }^{1,2} \text { ) } \\
\text { - Hypocontractile detrusor }{ }^{3,4}\end{array}$ & $\begin{array}{l}1 \text { suprasacral } \\
2 \text { supraspinal } \\
3 \text { subsacral / } \\
\text { lumbosacral } \\
4 \text { peripheral }\end{array}$ \\
\hline
\end{tabular}

neurogenic urinary storage dysfunction, this can be achieved using conservative, minimally invasive, and/or surgical treatment options:

\section{Conservative Treatment Options}

\section{Neurophysiological Background}

Despite the apparently more obvious cause of LUT storage dysfunction in neurological patients based on the impairment of aforementioned multilevel neuronal control, it is important to also consider the physiological mechanisms occurring within the LUT. This is of particular relevance since there are as yet no direct treatments available for most of the neurological lesions/diseases causing LUT storage dysfunction. Understanding the physiological processes in the LUT also on a receptor and neurotransmitter level, however, can help to detect useful targets for pharmacotherapy.

In previous decades, different receptors, chemical mediators and signal transduction pathways within the LUT have been discovered and described as being involved in normal and pathological LUT function [66]. Of those, the cholinergic system, including muscarinic receptors, is probably the best described and longest-known mechanism in the LUT $[67,68]$.

In order to contract, the detrusor requires an appropriate command, delivered by acetylcholine released from parasympathetic postganglionic nerve terminals.
Acetylcholine binds to the muscarinic receptors on the detrusor and activates G-protein-related pathways that lead to smooth muscle contraction [69]. Depending on the muscarinic receptor subtype that is activated, detrusor contraction is facilitated by (1) inhibition of adenylyl cyclase via M2 receptors and subsequent decrease of intracellular cAMP, and/or (2) phospholipase c activation via M3 receptors to generate inositol triphosphate which then releases $\mathrm{Ca}^{2+}$ from the sarcoplasmic reticulum [69]. Since intracellular $\mathrm{Ca}^{2+}$ release is regarded as the main trigger for smooth muscle contraction, M3 receptors are regarded as most relevant for the initiation of voiding contractions [69].

Beyond the detrusor, muscarinic receptors of all subtypes (M1 - M5) have been found elsewhere in the LUT [67, 68]: e.g., urothelium, suburothelium, afferent nerve fibers, and autonomic postganglionic nerve endings. Their exact role and function in these locations is not yet fully established. However, there is evidence that muscarinic receptors on the postganglionic nerve endings are involved in facilitation (M1) and inhibition (M2, M4) of axonal acetylcholine release [68]. In the urothelium and suburothelium, activation of muscarinic receptors can lead to release of neurotransmitters such as adenosine triphosphate (ATP), that in turn can modulate afferent nerve- and smooth muscle activity [70].

In the context of DO, both of idiopathic and neurogenic origin, alterations of muscarinic receptor expression and sensitivity have been observed and seem to contribute to the pathophysiological process of DO: e.g., muscarinic receptors in 
the detrusor tissue of patients with idiopathic detrusor overactivity (IDO) and neurogenic detrusor overactivity (NDO) demonstrated increased sensitivity to stimulation, compared to healthy controls [71] and decreased suburothelial expression [72]. In the animal model, SCI seem to alter the muscarinic receptor profile on the postganglionic nerve terminals towards upregulation of M3 and downregulation of M1 receptors [73, 74].

The sympathetic counterparts of muscarinic receptors are beta-adrenoceptors. Their activation, naturally by noradrenaline release from postganglionic sympathetic neurons of the hypogastric nerve, can mediate relaxation of the detrusor and thus contribute to the restoration of bladder storage function. Beta-3-adrenoceptors seem to be the most relevant in this context [75] and recent clinical trials have resulted in approval of a beta-3-adrenoceptor agonist for the treatment of bladder overactivity including DO [76, 77] (see paragraph on betaadrenoceptor agonists below).

In addition to the classical cholinergic/adrenergic mechanisms, there are other pathways, neurotransmitters, and receptors that have been described to play a role in bladder storage (dys-)function and thus may serve as relevant treatment targets [66]: e.g., purinergic system, cannabinoid system, nerve growth factor, Rho-kinase pathway, transient receptor potential (TRP) channels, prostanoid receptors, potassium channels, and vitamin D3 receptors. So far, purinergic receptors, TRP channels, and the cannabinoid system seem to constitute the most promising targets [66].

The purinergic system is based on the principle that ATP is released from the urothelium upon stretch and binds to purinergic receptors $(\mathrm{P} 2 \mathrm{X})$ on suburothelial sensory nerves which mediate the sensation of bladder filling. Increased levels of ATP release or purinergic receptor expression may contribute to increased sensitivity, i.e., urinary urgency, or detrusor overactivity [66]. In the bladders of patients with NDO, increased levels of nerve fibers expressing the purinergic receptor $\mathrm{P} 2 \mathrm{X} 3$ have been detected $[78,79]$. Patients with a clinical response to intravesical vanilloid treatment with resiniferatoxin showed decreased $\mathrm{P} 2 \mathrm{X} 3$ expression, whereas non-responders did not [78]. Similar effects were observed in response to botulinum neurotoxin A (BoNT/A) intradetrusor injections [80]. In SCI rats, which showed higher frequencies of spinal cord field potentials and non-voiding contractions compared to normal rats, application of $\mathrm{P} 2 \mathrm{X} 3$ antagonists A-317491 and AF353 was demonstrated to reduce both parameters [81, 82].

TRP cationic ion channels are universal sensors of physical and chemical stimuli that are ubiquitous in various tissues of the human body including the LUT [83]. Their basic mechanism is to allow cationic (e.g., $\mathrm{K}^{+}, \mathrm{Ca}^{2+}$ ) influx upon stimulation, causing secondary reactions dependant on the tissue in which the TRP channel is located, e.g., depolarization with elicitation of an action potential in neurons. Within the LUT, several TRP channels have been detected in various layers (including mucosa and detrusor) and on neuronal fibers innervating the LUT. Of such TRP channels, specifically TRPV1, TRPV2, TRPV4, TRPM8, and TRPA1 have been attributed to play a relevant role in normal and pathological LUT function $[66,83]$. As with the increased purinergic receptor expression in patients with NDO, TRPV1 expression was also found to be elevated in NDO patients $[84,85]$. Again, treatment with resiniferatoxin or BoNT/A intradetrusor injections was able to reduce TRPV1 expression in those patients responding also clinically to treatment $[80,84,85]$.

Despite their promising effects in human studies, the evidence for intravesical treatment with vanilloids such as capsaicin and resiniferatoxin is still very limited and adverse events including pelvic pain, facial flush, worsening of incontinence, autonomic dysreflexia, urinary tract infection, and haematuria are very frequent [86]. Intravesical vanilloids are not approved for treatment in LUTD / LUTS and have largely fallen into oblivion, particularly after the propagation of BoNT/A intradetrusor injections. However, based on their action on specific LUT receptors and afferent fibers, vanilloids are still of scientific interest and may undergo a clinical revival once more tolerable solvents for their application are developed [86].

The cannabinoid system in the LUT involves two G-proteincoupled cannabinoid receptors, $\mathrm{CB} 1$ and $\mathrm{CB} 2$, their endogeneous (e.g., anandamide, 2-arachidonoylglycerol) and exogeneous (phytocannabinoids, synthetic cannabinoids) ligands, and related enzymes for biosynthesis and degradation (e.g., fatty acid amid hydrolase, monoacylglycerol lipase) [87]. Hence, effects can be elicited directly by stimulation of the cannabinoid receptors or indirectly by inhibiting the degradation enzymes such as fatty acid amid hydrolase (FAAH). In SCI rats, treatment with the selective CB2 agonist O-1966 resulted in improved bladder function recovery which was associated with a significant reduction of inflammatory response in the spinal cord following injury [88]. In MS patients with NDO, delta-9tetrahydrocannabinol alone or in combination with cannabidiol applied as oral capsule or spray improved symptoms such as urinary incontinence and frequency [89]. However, symptomatic improvements were not reflected urodynamically and there were mild but frequent adverse events such as UTI, dizzinesss, headache, vomiting, and worsening of dry mouth [66, 89]. Although Sativex ${ }^{\circledR}$ is an approved drug, its indication in most countries is limited to treatment of refractory spasticity in patients with advanced MS. The overall clinical evidence for the use of cannabinoids in the treatment of NLUTD is still very limited and trials applying indirect cannabinoid stimulation, e.g., use of FAAH inhibitors, for the treatment of NLUTD, are lacking.

Despite the numerous potential treatment targets identified in different animal models, of which only few are neurogenic, i.e., SCI or MS, translation of findings into humans is a major challenge. Thus, approved pharmacotherapy for LUTD/ LUTS is still very limited and antimuscarinic drugs are still 
the mainstay of conservative therapy for bladder storage dysfunction (see paragraph below).

\section{Antimuscarinic Drugs}

In principle, antimuscarinics act as reversible competitive antagonists, that block the muscarinic receptors in the detrusor myocytes resulting in reduced detrusor excitability through acetylcholine release at parasympathetic nerve terminals [69]. Assuming urinary urgency and DO are the result of premature acetylcholine release from the parasympathetic nerves during the storage phase, the available antimuscarinic drugs will shift the dose response curve of acetylcholine to the right, i.e., more acetylcholine is necessary to cause the same effect or symptom, resulting in the postponement or attenuation of cholinergic stress in the detrusor. Clinically, this results in the typical improvements in LUTD / LUTS such as increased warning time, larger bladder capacities prior occurrence of urgency and DO, and reduced pressure amplitudes of DO [90-96]. This competitive antagonism is a dynamic process, the efficacy of which depends inter alia on the available concentration of the antimuscarinic drug at the neuromuscular junction in relation to the acetylcholine concentration. Thus, high dosages of antimuscarinics may cause enough detrusor sedation to result in increased post-void residual volume (PVRV) or even urinary retention [94, 97, 98]. However, with the clinically applied and approved antimuscarinic dosages, this seems to happen rarely - at least in patients with nonneurogenic overactive bladder symptoms (OABS) [99, 100]. Nevertheless, antimuscarinics still apply a verifiable effect on storage symptoms and DO $[90,91,96]$, raising the question why they seem to selectively act during the storage but not voiding phase. Certainly, antimuscarinics cannot differentiate or act differently across both phases and this observation may simply be a false conclusion, as many aspects of the pathogenesis of OABS and the interplay between muscarinic receptor expression, acetylcholine release and antimuscarinic drugs remain unknown. In addition, the treatment effect of currently available antimuscarinic drugs for LUTD/LUTS is often little greater than placebo [101] and their effect on the detrusor pressure amplitude during micturition has never been systematically analyzed. This would be of relevance for our understanding of antimuscarinic action and the lack of voiding symptoms does not per se prove that there is no effect on detrusor contractility during voiding at all. Yet, potential relationships between antimuscarinic effects during the storage and voiding phase remain unclear, e.g., if the reduction in DO or urgency corresponds to a reduction in voiding contraction. The explanation that during micturition the expected massive neuronal release of acetylcholine cannot be countered by antimuscarinic drugs in the approved dosages [102] appears reasonable in view of the competitive antagonistic mechanism of action of antimuscarinic drugs but still leaves unclear what happens during the storage phase causing urinary urgency and DO that can be alleviated by antimuscarinics. As mentioned, some premature neuronal acetylcholine "leakage" that can be covered by antimuscarinic drugs at the approved dosages may be involved, providing support to the neurogenic hypothesis of OABS [103], but non-neuronal acetylcholine release and muscarinic receptors on other tissues than detrusor may also play a role.

Recent studies in animals and isolated human bladder tissue provide evidence for acetylcholine release from sources other than the parasympathetic nerve terminals, i.e., urothelium and suburothelial myofibroblasts, and the presence of muscarinic receptors on afferent nerves [102, 104]. In addition, it has been demonstrated that antimuscarinic drugs can suppress adenosine triphosphate release form the urothelium $[102,105]$. The antagonization of acetylcholine release from non-neuronal sources and the modulation of neurotransmitter release at the urothelial and suburothelial level by antimuscarinic drugs may influence localized autonomous non-micturition contractile activity [106] and afferent activity, which in consequence reduces OABS [102]. However, the detailed mechanism in humans, especially if there is a direct afferent effect of muscarinic drugs, requires further elucidation.

Although some newer antimuscarinic drugs show some selectivity for the M2 and/or M3 receptors on the detrusor, all antimuscarinic drugs for LUTD / LUTS treatment still bind to other muscarinic receptors elsewhere in the body causing, to various extents, adverse events such as dry mouth, constipation, blurred vision, somnolence, dizziness, and cognitive impairment [107]. The main route of antimuscarinic drug administration is oral, through which extended-release compared to immediaterelease formulations are usually better tolerated and enable a once-daily application. Alternative administration routes, such as transdermal and intravesical application, are available and may be an option for reducing some side effects [107].

The voluminous literature and evidence available for the use of antimuscarinic drugs is mainly related to the treatment of OABS which occurs per definition only in patients without any neurological etiology of their LUTS for whom these drugs have been mainly developed and marketed [91, 96, 108]. However, there is also some evidence for the efficacy of antimuscarinic drugs in NDO [90, 92, 109]. In conjunction with the relatively good safety profile and tolerability, as well as being a conservative treatment strategy, are the reason antimuscarinic drugs also remain first line treatment for NDO [65]. Data on the urodynamic effects of antimuscarinics in NDO are primarily available for "older" drugs such as oxybutynin, trospium chloride, propiverine, and tolterodine and show increases in maximum cystometric bladder capacity of about $120 \mathrm{~mL}$ and reductions in maximum detrusor pressure amplitude of about $28 \mathrm{cmH} 2 \mathrm{O}[92,109]$. Data for urodynamic effects of newer drugs in NDO such as 
darifenacin, solifenacin, or fesoterodine are scarce. Solifenacin seems to be beneficial but with somewhat less impact on maximum cystometric bladder capacity and maximum detrusor pressure [110].

For some patients with NDO, antimuscarinic drugs are not efficacious at the available dosages [109]. This may be related to the fact that current antimuscarinics as competitive antagonists cannot resist the likely massive cholinergic output from the parasympathetic nerve terminals during full-blown NDO. Here, some authors suggest the application of higher dosages either of the same or as a combination of different antimuscarinic drugs [111-115]. However, this is off-label use without sufficient evidence and adverse events might be more pronounced, decreasing the benefit/risk ratio and patient compliance with this therapy $[65,90]$.

\section{Beta-Adrenoceptor Agonists}

An alternative strategy is combined treatment of an antimuscarinic drug and the newer beta-3-agonist mirabegron, aimed at achieving a synergistic effect by targeting two different receptors without exceeding approved dosing [116, 117]. In addition to a small, retrospectively-analyzed case series suggestig beneficial urodynamic and clinical effects of such combination treatment [118], there is a very recently published randomized placebo-controlled trial available, concluding that mirabegron monotherapy with $50 \mathrm{mg}$ once daily improves both urodynamic variables and patient reported outcomes in patients with NDO [119]. However, this trial had a very short follow-up period of only 4 weeks and the main urodynamic parameters such as maximum detrusor pressure and maximum cystometric bladder capacity were not significantly improved, raising doubts as to the efficacy of mirabegron in the treatment of NDO. More comprehensive data are lacking. Moreover, mirabegron may not be a good option in the treatmet of patients prone to $\mathrm{AD}$ due to its sympathomimetic properties, which may cause elevated blood pressure and palpitations and potentially lead to more pronounced symptoms and blood presure elevations during $\mathrm{AD}$.

\section{Per- or Transcutaneous Neuromodulation}

Neuromodulative therapies aim to modulate neuronal signals in both afferent and efferent directions, exerting their effect by fairly slowly-occurring alterations of neuronal communication and circuitry. Thus, they must be distinguished from neurostimulation aiming at a direct response, i.e., muscle contraction, upon stimulation. The exact mechanism of action of neuromodulation for LUTD/LUTS remains unknown but it is hypothesized that, in the dorsal horn of the sacral spinal cord, bladder afferent activity may be inhibited through interneurons activated by somatic sensory pathways originating in the external genitalia, perineum, lower limb and muscles of the pelvic floor via the pudendal and/or tibial nerve $[120,121]$. This inhibitory interaction between larger somatic sensory fibers and small bladder afferents (A-delta or unmyelinated $\mathrm{C}$ fibers) may operate in a similar way to the 'gate control' theory of pain [122]. Animal studies suggest that pudendal nerve stimulation can elicit two effects [123]: (1) suppression of pelvic nerve activity to the detrusor by inhibition of the sacral micturition reflex at either the afferent input or the parasysmpathetic pre-ganglionic motor neurons and (2) activation of sympathetic neurones running in the hypogastric nerves causing inhibition of the parasympathetic efferent motor neurons at the level of the pelvic ganglia.

Based on these hypotheses, the most frequently investigated sites to apply per- or transcutaneous neuromodulation for the treatment of LUTD/LUTS are the dorsal genital nerve [124] as a terminal branch of the pudendal nerve and the tibial nerve [125].

The approach of using the pudendal and tibial nerve as therapeutic targets for NLUTD goes back at least to the publication by Parker M.M. and Rose D.K. in 1937, which demonstrated reduced DO in response to pin prick stimulation at the glans penis and sole of the foot in complete traumatic SCI patients [126]. In the 1970s, initial reports of electrical stimulation of terminal branches of the pudendal nerve, mainly using anal or vaginal plugs to reduce detrusor (over)activity, were published [127, 128]. Today, clitoral/penile, vaginal or rectal electrodes to reach the pudendal nerve or its terminal branches are commercially available, but transcutaneous electrical nerve stimulation (TENS) for LUTD / LUTS treatment is not limited to the genital/rectal area and may also be applied to sacral and suprapubic sites using conventional surface electrodes [124]. For percutaneous tibial nerve stimulation (PTNS), a 34-gauge needle electrode is inserted approximately $5 \mathrm{~cm}$ cephalad to the medial malleolus and posterior to the tibia with a surface electrode on the arch of the foot [121]. In some more recent studies, transcutaneous tibial nerve stimulation (TTNS) has been used, which works with another surface electrode instead of the needle and thus makes it more amenable to individual home-use.

Both TENS and PTNS/TTNS have been demonstrated to be effective on urodynamic and bladder diary parameters in patients with NLUTD [124, 125]. Specifically, TENS increased maximum cystometric capacity by $4-163 \mathrm{~mL}$, reduced maximum storage detrusor pressure by $3-58 \mathrm{cmH} 2 \mathrm{O}$, the number of bladder emptyings/ $24 \mathrm{~h}$ by $1-3$, and the number of incontinence episodes/24 h by $0-4$ [124]. PTNS/TTNS increased maximum cystometric capacity by $49-150 \mathrm{~mL}$, reduced maximum storage detrusor pressure by 4-21 cmH2O, the number of bladder emptyings/ $24 \mathrm{~h}$ by $3-7$, and the number of incontinence episodes/24 h by 1-4 [125].

Despite these promising beneficial effects, there are very few long-term results [129] and a lack of QoL data. Larger randomized controlled trials are needed to provide reliable evidence, which might be, in addition to the handling and 
necessity for regular application of treatment sessions, a reason that this kind of therapy is still not very commonly used, despite the commercial availability of inexpensive devices and the fact that adverse events are almost inexistent.

\section{Intermittent Self-Catheterization}

In addition to its obvious utility in emptying the urinary bladder, it is often necessary to add intermittent self-catheterization (ISC) to the management of bladder storage dysfunction in the neurological patient in order to achieve continence. It may even represent the first choice in patients with DO incontinence provoked by a reduced functional bladder capacity prior to the occurrence of the DO incontinence due to accumulation of residual urine volume. Post-void residual volume may even increase with therapies aiming to restore continence by detrusor sedation in order to reduce or prevent DO, i.e., antimuscarinic drugs, BoNT/A intradetrusor injections and augmentation cystoplasty. If such a residual volume becomes too large and the bladder is not regularly emptied, symptoms such as urinary urgency and incontinence may persist or reoccur due to a reduced functional capacity. In such cases, ISC is today's gold standard for regularly, efficiently, and autonomously emptying the bladder. A certain degree of hand function and in females also of pelvic and lower limb mobilization is required to adequately perform ISC and these aspects must be considered in the treatment strategy of LUTD in neurological patients.

Since its introduction in 1972 by Lapides [130], catheter models and characteristics have significantly improved and today there is a wide selection of high-tech catheters available, covering the needs of nearly every patient. More recent data and expert panels are in favor of single-use catheters with a hydrophilic coating $[131,132]$. However, further evidence from prospective randomized controlled trials evaluating catheter type (coated vs. uncoated) and catheterization technique (sterile vs. clean vs. aseptic; single-use vs. re-use) in a broader context, including evaluation of therapy compliance, QoL, and costs is needed.

\section{Other Conservative Treatment Options}

There are a few other alternative conservative treatment options available such as pelvic floor muscle training [133] and intravesical electrostimulation $[134,135]$. In particular pelvic floor muscle training under professional guidance is a first line conservative treatment option that should be considered if appropriate to improve LUT function. However, the level of evidence for these therapies in the treatment of NDO is very limited as randomized controlled trials are lacking. Moreover, pelvic floor muscle training and intravesical electrostimulation require at least some preserved sensory- motor function to be effective and therefore may be suitable only for a subset of patients with NDO.

\section{Minimally Invasive Treatment Options}

\section{Implantable Devices for Tibial Nerve Stimulation}

To facilitate tibial nerve stimulation outside the hospital or clinic setting implantable devices are also available [136-139]: Urgent-SQ® (formerly Uroplasty then Cogentix Medical, now Laborie, Mississauga, ON, Canada), RENOVA ${ }^{\circledR}$ (BlueWind Medical, Herzliya, Israel), and StimGuard® implantable miniature device (StimGuard, Pompano Beach, FL, USA). These devices consist of a small electromagnetic impulse receiver requiring no battery with stimulation electrodes and an external electromagnetic impulse generator. The impulse receiver with electrodes is implanted next to the tibial nerve, usually above or at the ankle, and the external impulse generator is strapped around the ankle during therapy sessions to allow wireless transmission of the stimulation signal to the implanted receiver to induce stimulation. Despite this smart approach and some decent long-term-data [136], currently available studies focus on non-neurogenic overactive bladder (NNOAB) patients only and the level of evidence is generally low due to the lack of randomized controlled trials [136-139]. Hence, currently, no recommendation or conclusion on the use in neurological patients can be made.

\section{Sacral Neuromodulation}

Similar to the principles described for TENS and PTNS/TTNS earlier, sacral neuromodulation (SNM) aims to modulate the activity of one of the neural pathways affecting the preexisting activity of another neural pathway, i.e., LUT-related afferent and efferent pathways, via spinal interneurons and synaptic interaction. Available evidence suggests that both spinal reflexes and supraspinal circuits involved in LUT control are modulated in this way $[140,141]$.

Although SNM has been commercially available for more than 20 years, it was not initially used for NLUTD in the first place, as it was believed that intact neuronal innervation is a prerequisite for SNM to be effective [142-144]. In contrast to the per- or transcutaneous neuromodulation, SNM is an implantable therapy that delivers constant stimulation to the sacral nerve roots. For the purposes of LUTD/LUTS treatment, electrodes are usually placed next to the S3 root as it passes through the sacral foramen.

In a first stage, the quadripolar electrodes (tined lead, Medtronic, Minneapolis, Minnesota, USA) are placed in a minimally-invasive fashion by puncturing the 3rd sacral (S3) foramen under fluoroscopic guidance and implanting the tined lead using the Seldinger technique with a special introducer sheath $[145,146]$. The procedure can be performed under local 
anesthesia, which allows for evaluation of sensory responses and the anal motor response. However, sensory testing during tined lead placement for sacral neuromodulation does not necessarily improve clinical outcomes of neuromodulation [147]. Following tined lead placement, which can be performed unior bilaterally, electrode wires are tunneled subcutaneously and connected to an external stimulator [145, 146]. During a subsequent test phase, different neuromodulative settings, i.e., number of active electrodes, stimulation frequency, and stimulation strength, can be evaluated with respect to treatment efficacy. If an improvement of at least $50 \%$ can be achieved with a certain parameter setting and the patient is happy to go for the full implantation, the permanent neuromodulator (Insterstim or Interstim II, Medtronic. Minneapolis, Minnesota, USA) is implanted into the gluteal subcutaneous fat tissue $[145,146]$.

To date, a pooled success rate of $68 \%$ in the test phase and $92 \%$ in the fully implanted condition has been described for SNM in the treatment of NLUTD [140]. Despite these very promising numbers, the current evidence is based on rather small prospective cohort studies and retrospective case series only and consequently constitutes an evidence level too low to allow a final conclusion or recommendation [65]. The first randomized controlled trial is currently ongoing (NCT02165774) [148].

Adverse events seem to be more frequent after complete implantation than during the test phase and comprise lead migration (7\%), pain at the neuromodulator implantation site $(5 \%)$, infection at neuromodulator implantation site (5\%), hypersensitivity to stimulation (4\%), infection at the lead site $(2 \%)$, pain at the lead site $(1 \%)$, lead fracture $(1 \%)$, migration of the neuromodulator (1\%), malfunction of the neuromodulator (1\%), and others (4\%) [140].

A more recent study using bilateral SNM for treatment of LUTD in patients after complete traumatic SCI demonstrated excellent results on bladder, bowel and sexual function [149]. NDO in particular could be prevented resulting in normocapacitive and normo-active bladders in the storage phase. This surprisingly advantageous effect was attributed to the early time point of implantation, i.e. 3 months after SCI. An early application of SNM may at least partly prevent the formation or emergence of pathological reflex circuits in the spinal cord below the lesion during the spinal shock phase that otherwise results in NDO. Also, detrusor inhibitory effects via the sympathetic hypogastric nerve may be activated or facilitated through SNM, contributing to a degree of autonomic balance below the lesion that otherwise is deranged due to the SCI [149]. However, this potentially promising approach has only been described in this publication of 10 cases and long-term, multi-center, and randomized controlled data are lacking.

Very recently, newer devices for SNM have been developed, e.g., Virtis ${ }^{\circledR}$ (Nuvectra, Plano, TX, USA) and
Axonics Sacal Neuromodulation System (Axonics, Irvine, CA, USA), that provide improvements with regard to MRcompatibility and ability to recharge the implanted neurostimulator. Since none of the devices are yet approved for treatment, the clinical experience is currently still very limited and data for use in NLUTD are lacking. However, initial study results appear promising, at least in NNOAB patients, not only with respect to symptom relief but also in terms of cost-effectiveness [150-152].

\section{Botulinum Neurotoxin A Intradetrusor Injections}

BoNT/A is a highly potent neurotoxin that has been in medical use for several decades in the treatment of localized motor dysfunction and muscle spasms such as blepharospasm, cervical dystonia, strabism, and hemifacial spasm [153]. Beyond motor/movement disorders, also treatment of autonomic dysfunction such as sialorrhea, hyperhidrosis, and detrusor overactivity using BoNT/A injections has been explored.

The proposed general mechanism of action of BoNT/A is the irreversible cleavage of the SNAP-25 protein in the axon terminal of the neuromuscular junction. SNAP-25 is a SNARE (soluble N-ethylmaleimide sensitive fusion protein attachment receptor protein) that is responsible for the fusion of the synaptic vesicles into the synaptic membrane and subsequent release of the neurotransmitter, i.e., acetylcholine, from the vesicles into the synaptic cleft $[153,154]$. The disenabling of SNAP25 by BoNT/A prevents or reduces acetylcholine release upon arrival of an action potential at the axon terminal and hence results in a chemo-denervation of the target muscle. Depending on the applied dosage, such chemo-denervation can reduce elevated muscle tone or spasticity or even paralyze the muscle. Despite the permanent cleavage of the SNAP-25 protein, the duration of effect of BoNT/A is limited to several weeks or months depending inter alia on the type of targeted nerve terminal (somatic vs. autonomic) and applied dosage [154-156]. The mechanism presumed to be responsible for the reversibility of the neuroparalysis is synaptic sprouting with formation of new neuromuscular junctions [154, 155].

Due to the large molecular size, i.e., $150 \mathrm{kD}$ for the core toxin alone, BoNT/A cannot be absorbed through skin or mucosa and needs to be injected to reach the target tissue. Intradetrusor injections can be applied via a flexible or rigid cystoscope [157]. Although, several aspects of the injection technique, i.e., number of injection sites, volume per injection and injection depth are still matter of discussion, the currently approved dosage and technique for the treatment of NDO implies a total dose of 200 units onabotulinumtoxinA, as $1 \mathrm{~mL}(\sim 6.7$ Units) injections across 30 sites into the detrusor [158, 159].

There are several different BoNT/A formulations on the market, i.e., onabotulinumtoxin $\mathrm{A}\left(\right.$ Botox $\left.^{\circledR}\right)$, abobotulinumtoxin $\mathrm{A}$ (Dysport $\left.{ }^{\circledR}\right)$, incobotulinumtoxinA $\left(\mathrm{Xeomin}^{\circledR}\right)$ of which 
currently only onabotulinumtoxinA is approved for the treatment of NDO. However, two ongoing Phase-III studies using abobotulinumtoxinA in the treatment of NDO (NCT02660138, NCT02660359) may lead to approval of abobotulinumtoxinA in the near future.

OnabotulinumtoxinA 200 or 300 units significantly reduced the mean frequency of urinary incontinence per week by 11 episodes in patients with NDO at 6 weeks after treatment compared to placebo. In the same time, maximum cystometric capacity significantly increased on average by $145 \mathrm{~mL}$ and maximum detrusor pressure decreased on average by $33 \mathrm{cmH} 2 \mathrm{O}$ compared to placebo [160].

In selected cases, 100 units may be sufficient to reduce NDO and associated symptoms but still allow voluntary micturition [161].

BoNT/A intra-detrusor injections are a safe treatment with few adverse events that are mostly self-limiting such as haematuria (relative risk 1.7), injection site pain, procedurerelated urinary tract infection (relative risk 1.47), and generalized muscle weakness (relative risk 2.59) [156, 160]. However, urinary retention (relative risk 5.58) can occur and needs to be explained to the patient prior to injection as it may require the use of intermittent or indwelling catheters $[156,160]$.

Due to the limited effect duration, repeated treatments are necessary in the majority of cases, which seems to be feasible without loss of efficacy [162-164]. Caution should be taken in regard to multidisciplinary BoNT/A treatments to prevent unintended overdosage. It is recommended to not exceed a total dose of 360 units onabotulinumtoxin-A administered in a 3 month interval [158].

Based on the existing high-level evidence, BoNT/A intradetrusor injections are recommended as second line treatment for NDO refractory to antimuscarinic treatment [65]. Usually, prior antimuscarinic treatment is stopped shortly after BoNT/A intradetrusor injections, but may be continued as concomitant treatment in selected cases to optimize efficacy if required. Antimuscarinic treatment may be restarted once the BoNT/A effects starts to fade and symptoms recur to bridge the time until reinjection.

Similar to antimuscarinic drugs, recent basic research has revealed multiple alternative or additional sites and mechanisms of action of BoNT/A within the LUT [165]. Such alternative mechanisms include modulation of neurotransmitter and -peptide release, receptor trafficking, and neurogenesis both on peripheral but probably also at a central level [165].

Moreover, BoNT/A has been evaluated in applying intraprostatic injections, which seem to improve prostate related LUTD/LUTS [166]. This may be specifically relevant for male neurological patients who show a prostatic component in their LUTD/LUTS but in whom surgical intervention would bear increased risk of urinary incontinence [167-169].

\section{Surgical Treatment Options}

\section{Sacral De-afferentation (With/Without Sacral Anterior Root Stimulation)}

Considering NDO as result of an overshooting spinal reflex because of impaired or lost inhibitory control from supraspinal centers similar to musculoskeletal spasticity, transection of the afferent branch of the reflex arc would result in the disruption of this spinal reflex and consequently abolish NDO. Sacral deafferentation is a neurosurgical procedure with the aim of transecting the dorsal S2-S5 nerve roots. It requires a laminectomy to access the spinal nerve roots and opening of the dura to microsurgically separate the ventral from the dorsal roots prior to transection [170]. An extradural approach is also possible but implies a higher risk of incomplete de-afferentation and injury of the anterior root due to a less definite separation between anterior and posterior root segments compared to the intradural approach [171]. Intraoperative urodynamics and cardiovascular monitoring allow the functional differentiation between ventral and dorsal roots upon electrical stimulation [170]. After this procedure, a form of catheterization, i.e., ideally ISC, is required to empty the bladder.

Complete de-afferentiation of the S2-S5 roots can be achieved in $73-95 \%[170,172,173]$ resulting in an acontractile, flaccid detrusor and continence without further treatment in 83-85\% [170, 173]. Moreover, coexisting AD can also be abolished with this treatment in about 59-61\% $[172,173]$.

The main drawbacks of this treatment are the invasive and irreversible character of the procedure with the necessity of performing a laminectomy and to irreversibly transect intact nerve tissue resulting in loss of potentially preserved sensory function of the pelvis and lower limbs. Moreover, sexual function (e.g., reflex erections) and the defecation reflex will be lost. These drawbacks are the main reason why few patients are today willing to undergo such treatment. A possibility for regaining function and to even empty the bladder through the urethra without using a catheter is to implant a sacral anterior root stimulator (SARS) after sacral de-afferentation. A SARS, e.g. Finetech-Brindley bladder stimulation system, can be implanted in the same procedure following sacral deafferentation by placing special electrodes bilaterally around the anterior roots S2-S4. By placing each root in a separate electrode segment, independent control of pelvic functions is possible, for example S3 stimulation for detrusor contraction and micturition, $\mathrm{S} 3+\mathrm{S} 4$ stimulation for rectal pressure rise and defecation, and S2 stimulation to induce penile erection [170]. However, adjustments may differ on an individual level and while the efficacy of the SARS for micturition and defecation seems to be good, it is less effective for sexual function.

Although the SARS is sometimes referred to as a bladder pacemaker in the same manner as the SNM system, both 
procedures must be clearly distinguished. The SARS is much more invasive, needs much higher amplitude of stimulation above the pain threshold, and thus has a much narrower indication, reserved to selected SCI patients.

\section{Augmentation Cystoplasty}

Augmentation cystoplasty is a well-established abdominal surgical procedure that aims to reduce detrusor contractility and to enlarge bladder capacity. Detrusor contractility is reduced by removing part of the detrusor or cleaving the detrusor at the dome and thereby interrupting its muscular continuity. Bladder capacity is increased by replacing or augmenting the bladder with bowel tissue. In addition, augmentation cystoplasty can be combined with a continent cutaneous urinary diversion to facilitate ISC via an abdominal site, when ISC via the urethra is impossible or difficult [174].

Although several types of gastrointestinal tissues have been used for augmentation cystoplasty [175], i.e., the stomach, ileum, colon, or sigmoid, ileum is nowadays the most frequently used tissue, generally due to its slightly more advantageous properties with regard to intraoperative handling, postoperative complications, and effectiveness [175].

Using an augmentation cystoplasty for NDO treatment, reduction of MDP from 60 to $15 \mathrm{cmH}_{2} \mathrm{O}$ and an increase in MCC of $166-500 \mathrm{~mL}$ can be achieved, contributing to continence rates of $69-88 \%$ [176-180]. In addition, augmentation cystoplasty has been described as reducing VUR [181]. Patients with concomitant neurogenic sphincter insufficiency may require a complementary, anti-stress urinary incontinence (SUI) procedure, e.g. aponeurotic sling or artificial sphincter to achieve continence.

Augmentation cystoplasty requires some hospitalization time (2-4 weeks) but has a rather low mortality rate of 0 $3.2 \%$ [175]. However, there are several moderate to severe complications that can occur in the short and long term [176-178, 180, 182]: urinary stones (6-21\%), recurrent symptomatic UTI $(20 \%)$ including recurrent pyelonephritis (1.5$11 \%)$, ileus (1.9-11.7\%), chronic diarrhea (7-18.6\%), perforation $(0.75-4 \%)$, and fistulas $(0.4-1.3 \%)$. In addition, metabolic complications can occur due to altered absorption/ reabsorption of metabolic products in the augmented bladder and in the shortened gastrointestinal tract. Thus, type and severity of metabolic complications largely depend on the type and length of the resected gastrointestinal tissue. Metabolic complications include: hypochloremic acidosis, lipid malabsorption, vitamin B12 deficiency, and bile acid deficiency [183]. Patients with a catheterizable cutaneous derivation might experience additional complications regarding the urinary stoma [184-186]: stomal stenosis (6-15\%), channel leakage $(9 \%)$, false passage $(6 \%)$, and stomal prolapse $(5 \%)$.

Nevertheless, patient satisfaction is usually high [182], as most patients already suffered for a considerable time period from severe DO and usually had several failed treatment attempts before being considered for augmentation cystoplasty. However, only patients able and willing to perform ISC should be considered for this kind of treatment, as otherwise the patient is not gaining much from this kind of invasive therapy.

\section{Cystectomy with Urinary Diversion}

If none of the aforementioned treatment options can sufficiently reduce NDO and/or significant structural alterations have already occurred, it may become necessary to remove the entire bladder as a last resort. It is thus the most definite form of NDO treatment and requires the formation of a urinary diversion that can be constructed to be continent or incontinent.

Operative and postoperative risks and complications are similar to those of the augmentation cystoplasty. However, complete cystectomy and creation of a urinary diversion is usually more complex and time-consuming and requires the re-implantation of the ureters, which implies the risk of ureteral stenosis.

For a continent urinary diversion, different forms of pouches and neo-bladders made of detubularised bowel segments are available and can be selected depending on the patient's needs and physical preconditions and the surgeon's expertise [187, 188]. Again, it is important to consider the patient's abilities and preferences with regard to emptying the new pouch or bladder in advance.

For an incontinent urinary diversion, which is usually somewhat less complex and less prone to complications than a continent diversion, the ureters are connected to a short, detached ileum segment that is then diverted through the abdominal wall outwards and connected to the skin [189]. This form of urinary diversion is also called ileal conduit or Bricker diversion, named after Eugene M. Bricker who described this procedure for the first time [189].

As the urine is now continuously and directly draining outwards, a urine bag has to be placed on the stoma site to collect the draining urine.

Such an intervention certainly interferes with the body image of most patients, but in addition to a high probability of UUT protection from elevated pressures, it offers the possibility to independently manage urinary drainage with less expenditure of supplies and time compared to other treatment strategies that require regular catheterisation, medical treatment (antimuscarinc drugs, BoNT/A intradetrusor injections) and follow-up (urodynamic investigation).

However, changes in kidney function and morphology, stenosis of the ureteroileal and ileocutaneous junction, and bowel dysfunction are known postoperative complications [190, 191].

\section{Alternative Treatment Options for Selected Patients}

In principle, the reduction of elevated storage pressures in the LUT and protection of UUT can be achieved by diminishing 
outflow resistance to a minimum in order to guarantee sufficient urine outflow from the bladder prior to the onset of elevated pressures. However, it has to be considered that the two treatment options ( $a$ and $b$ ) mentioned below do not actually restore or maintain a low pressure reservoir but rather aim at continuous low pressure drainage leaving the restoration of the native bladder as a reservoir unconsidered, which may work for selected patients but is also one of the main drawbacks of these treatment strategies contributing to their associated complications in short- and long-term.

(a) Insertion of an indwelling catheter either transurethrally or suprapubically and left on permanent drainage would help to reduce storage pressures and post void residual urine by direct continuous low pressure drainage. However, indwelling catheters are associated with several complications such as recurrent or chronic UTI, stone formation, urethral erosion (with transurethral catheters), increased risk of bladder cancer, and reduction of sperm quality and motility and are hence not generally recommended [65, 192-194] but may be an option for selected patients not able to perform ISC and who are not suitable for more invasive therapies such as urinary diversion. Nevertheless, an indwelling catheter itself does not treat DO and associated complications such as $\mathrm{AD}$ will persist and become evident each time the catheter occludes [195]. Moreover, constant urinary drainage required here to avoid elevated storage pressures may lead to significant loss of capacity over time and consecutive urinary leakage transurethrally and/or alongside the catheter [196].

(b) Transurethral sphincterotomy plus further subvesical desobstruction if required (e.g., resection of prostate and/or bladder neck tissue), implantation of a urethral stent, or BoNT/A intrasphincteric injections (off-label use) are options for reducing outflow resistance to enable low pressure urine drainage from the LUT. Although there are several cohort studies reporting promising results for each technique, i.e., reduction of maximum detrusor pressure and PVRV as well as lower incidence of hydronephrosis and AD [54], there are specific complications such as the necessity for repeated procedures due to urethral scarring, bladder neck obstruction, inefficient urodynamic improvement, stent migration/erosion, and stone formation. In addition, there are only very few randomized controlled trials available with inconclusive urodynamic data and a lack of QoL data, hampering clear recommendations $[65,197]$ and official approval for the use of BoNT/A in this context. Moreover, the mentioned techniques based on their principle of lowering outflow resistance will not reduce DO but lead to increased urinary incontinence and are thus mainly applicable to male patients who can wear a condom catheter to collect the urine.

\section{Restoration of Urethral Urine Storage Function}

Urinary incontinence has a devastating impact on QoL as it demonstrates loss of bodily control in its most inconvenient and unpleasant way, make LUT care the most challenging issue in the patient's daily life, and can itself drive patients into depression [198-200]. Furthermore, urinary incontinence can negatively affect the skin due to frequent contact with urine and/or the necessity to wear pads or diapers which facilitates the development of wounds/ulcerations and dermal infections [201-203].

Despite the frequent association of NDO with urinary incontinence [204], adequate treatment of NDO alone may be either insufficient to prevent urinary incontinence or even evoke urinary incontinence.

Sometimes, behavioral aspects have to be considered and augmented, as even the best NDO treatment is not meant to create a low pressure and continent urinary reservoir that needs to be emptied just once daily. In this regard, the patient's expectations and post-treatment responsibilities have to be clearly discussed. Behavioral treatments such as timed voiding/catheterization or adaption of fluid intake may help to prevent urinary incontinence in patients with impaired bladder sensibility or increased evening fluid intake, respectively [205].

Nevertheless, patients with an insufficient closing mechanism at the bladder neck and/or external urethral sphincter due to a lack or impairment of neurogenic innervation of these structures will most likely suffer from neurogenic SUI. In such cases, the main treatment principle is to increase outlet resistance. Hence, prior to application of such treatments, it is absolutely mandatory that NDO is either absent or at least adequately treated to prevent high pressure conditions and consequently a risk of renal damage.

Four different types of surgical interventions can be distinguished: (1) bladder neck/urethral reconstruction, (2) injectables (e.g., bulking agents), (3) suspensions (e.g., Burch, suburethral tapes and slings), and (4) prostheses (e.g., artificial urinary sphincter).

\section{Bladder Neck/Urethral Reconstruction}

Urethral lengthening in the form of an intravesical extension of the urethra using a bladder wall flap creates a valvular closure of the urethra with increasing filling of the bladder [206-210]. The original technique described by Young-Dees-Leadbetter was modified in recent decades by different urological surgeons mainly in pediatric patients with bladder extrophy [206, 211-214]. These techniques provide continence rates of 50-94\% [206, 207, 211, 215, 216]. However, such bladder neck/urethral reconstructions require regular ISC to empty the bladder and often prior or simultaneous bladder augmentation to secure low pressure storage [217]. Compared to the artificial 
urinary sphincter (AUS), continence rates seems to be similar but with a significantly lower reoperation rate [218].

\section{Injectables}

Injectables can consist of different materials (e.g., autologous fat, collagen, silicon, carbon, Teflon ${ }^{\circledR}$, poly-acrylamide hydrogel) and are injected transurethrally below the bladder neck to create a sub-mucous cushion/bulking of the urethra that cause obstruction to withhold the urine. Despite some recent promising findings $[219,220]$, the current literature does not provide sufficient evidence for this kind of therapy [221] and long-term results in patients with neurogenic sphincter deficiency seems to be rather poor [222].

\section{Suspensions}

Suspension therapies aim to restore or to improve urethral and/or bladder neck position and support, thereby enhancing the bladder neck or sphincteric closing mechanism. These are established treatment methods for female SUI [223, 224] and have recently been introduced also for male SUI $[225,226]$. Alongside traditional techniques such as Burch colposuspension, there are several different forms and materials of slings and tapes available. In patients with NLUTD, the use of autologous rectus abdominis fascia slings in a pediatric or adolescent population with or without simultaneous augmentation cystoplasty has been reported most commonly, demonstrating excellent results and low complication rates [227-237]. Synthetic tapes also seem to be suitable and effective for neurogenic SUI [238-240], except where a tight sling is necessary to provide adequate continence as there is a marked increase in the erosion risk.

\section{Prostheses}

Prostheses for neurogenic SUI treatment comprise implantable devices that cause adjustable mechanical obstruction or closure of the urethra and/or bladder neck. Autologous prostheses for sphincter augmentation have also been successfully explored using gracilis myoplasty around the bladder neck or urethra [241-244]. The use of autologous tissue around the urethra and bladder neck may reduce the risk of infection and erosion compared to artificial implants, especially in conditions where increased tension needs to be applied and ISC is performed. Nevertheless, an implanted pulse generator is required to stimulate the gracilis prosthesis to obtain contraction and urethral closure, respectively. Data on this procedure are scarce and, due to the rather sophisticated surgical approach, this technique is not widely-used.

Regarding artificial prostheses two options are available, the AUS (e.g., AMS $800^{\circledR}$, ZSI $375^{\circledR}$ ) and the inflatable para-urethral balloons (ACT ${ }^{\circledR} /$ ProACT $^{\circledR}$ ).
Currently, the most widely-used AUS model (AMS $800^{\circledR}$, formerly American Medical Systems, now Boston Scientific, Marlborough, MA, USA) consists of 3 major components, the inflatable cuff, the pump, and the pressure-regulating balloon. All three components are implanted and connected via special flexible but non-colliding tubes, allowing hydraulic function of the sphincter. The inflatable cuff is placed around the bulbar urethra (in men) or bladder neck (in men after prostatectomy and women or in some neurogenic indications) and connected to a control pump that is placed in the scrotum (in men) or labium majus (in women). The balloon is placed in the subperitoneal space lateral to the bladder. Activating the pump deflates the cuff by pumping water from the cuff into the balloon, from where it flows back into the cuff due to the hydraulic gradient between balloon and cuff. The re-closing of the cuff takes 2-4 min during which the patients can empty the bladder via spontaneous voiding or via ISC. ISC may be performed even with a closed AUS but the risk of urethral injuries may increase. The AUS is suitable for both men and women. Due to its high efficacy, the AUS is today's gold standard in the therapy of SUI [226]. Patients with neurogenic SUI, in whom the natural sphincter is insufficiently working due to damage of its neuronal control, also have greatly benefited from this therapy [245]. The success rate (proportion of continent patients) in patients with neurogenic SUI lies between 23 and 91\% (mean 73\%) [246-253].

Frequent complications for this procedure are erosion, infection, and mechanical/device-related failure that cause a reoperation rate for revisions and/or explantations of 16 to $80 \%$ [246, 247, 249-252].

Murphy et al. compared treatment outcomes between patients with neurogenic SUI and patients with non-neurogenic SUI [248]. According to this study, patients with neurogenic SUI tend to have complications more frequently that were not related to mechanical or device-related failure [248]. Bersch et al. reported very promising long-term results of a modified AMS800 system in patients with neurogenic SUI [254]. This modified system has the advantage that it works without the pump and is thus less susceptible to device-related defects and less costly [254]. Instead of the pump, a subcutaneous port is implanted that enables postoperative adjustments of the cuff-pressure. This system also seems to have some advantage with regard to the risk of pumperosion in wheelchair-bound female patients [254]. In addition, cuff pressure can be adjusted at any later time point via the subcutaneous port. Using cuff only AUS implantation in conjunction with an augmentation cystoplasty seems to be another alternative with very few AUS specific complications [255].

Inflatable paraurethral balloons are a relatively new minimally invasive technique that offers the advantage of postoperative adaption of the balloon size and consequently the degree of urethral obstruction [256, 257]. The balloons are placed bilaterally to the urethra at the bladder neck (in women) or at the membranous urethra (in men). Each balloon has a 
port that is placed into the ipsilateral scrotum or labium majus. The inflation is performed during follow-up visits with saline via the port of each balloon. Depending on the volume, the balloons cause a functional obstruction that should keep the urine within the bladder during situations of increased abdominal pressure. The use of this prosthesis in neurogenic SUI has demonstrated promising results $[258,259]$. Despite a lower efficacy compared to the appliance in non-neurological patients [260, 261], which is most probably related to the more severe sphincter insufficiency in neurogenic SUI, this prosthesis can significantly improve neurogenic SUI also in the long term with about $40 \%$ of patients reaching complete continence $[258,259]$. Due to the minimally invasive approach also with regard to explantation, $\mathrm{ACT}^{\circledR} / \mathrm{ProACT}^{\circledR}$ may be a particular valuable option for patients with mild to moderate neurogenic SUI who are not willing, not suitable or not yet ready for more invasive procedures or more complex implants. Nevertheless, randomized controlled trials are lacking, hampering clear recommendations.

\section{Summary and Conclusion}

Without doubt, the achievements of previous decades in the management of urinary storage dysfunction have significantly contributed to improvents in QoL, health, and survival of neurological patients affected by NLUTD. The cornerstones of urine storage dysfunction in neurological patients are ISC, antimuscarinic drugs, intradetrusor BoNT/A injections, augmentation cystoplasty, urinary diversion, and artificial urinary sphincter. However, these treatments have not advanced much recently. Moreover, with the exception of onabotulinumtoxinA intradetrusor injections, the level of evidence of many therapy options specifically regarding their appliance in neurological patients is quite low.

New therapy options are on the horizon but translation of findings from animal models into humans is still a major challenge that often fails. But even of treatments that are available or approved for use in NLUTD, the detailed mechanism of main and auxiliary actions are often only poorly understood, e.g. sacral neuromodulation, effect of BoNT/A on afferent signaling. Here, further research efforts may help or enable us to better use the full potential of already available treatments while attending new options.

Since there is no stable neurological disease in regard to NLUTD, efficiency of a chosen management strategy requires regular urodynamical reevaluation, particularly in individuals with a high risk profile, e.g. detrusor overactivity with or without detrusor-sphincter-dyssynergia, or with already evident structural or functional changes to LUT or UUT, e.g. VUR or renal ectasia.

\section{Compliance with Ethical Standards}

Conflict of Interest Ulrich Mehnert, Stefan de Wachter, and Philip E.V.A. van Kerrebroeck have nothing to disclose. Emmanuel ChartierKastler reports personal fees from Allergan, Astellas, Boston Scientific, Coloplast, Promedon, B Braun, Ferring, Uromems, Medtronic, Axonics, and non-financial support from Ipsen Biotech, all outside/unrelated the submitted work. Gommert A. van Koeveringe reports grants and personal fees from Astellas, personal fees from Boston scientific, grants and personal fees from Solace therapeutics, non-financial support from Zambon, all outside/unrelated to the submitted work.

Open Access This article is distributed under the terms of the Creative Commons Attribution 4.0 International License (http:// creativecommons.org/licenses/by/4.0/), which permits unrestricted use, distribution, and reproduction in any medium, provided you give appropriate credit to the original author(s) and the source, provide a link to the Creative Commons license, and indicate if changes were made.

\section{References}

1. Patel AK, Chapple CR. Anatomy of the lower urinary tract. Surgery (Oxford). 2008;26(4):127-32.

2. de Groat WC. Integrative control of the lower urinary tract: preclinical perspective. Br J Pharmacol. 2006;147 Suppl 2:S25-40.

3. Blok BF, Holstege G. The central control of micturition and continence: implications for urology. BJU Int. 1999;83 Suppl 2:1-6.

4. Mehnert U (2009) Technologies for the rehabilitation of neurogenic lower urinary tractdysfunction. In: Dietz V, Nef T, Rymer Z (eds) Neurorehabilitation technology. Springer, Berlin Heidelberg New York, pp. 413-439.

5. Mehnert U, Nehiba M. Neuro-urological dysfunction of the lower urinary tract in CNS diseases: pathophysiology, epidemiology, and treatment options. Urologe A. 2012;51(2):189-97.

6. de Seze M, Ruffion A, Denys P, Joseph PA, Perrouin-Verbe B. The neurogenic bladder in multiple sclerosis: review of the literature and proposal of management guidelines. Mult Scler. 2007;13(7):915-28.

7. Winge K, Skau AM, Stimpel H, Nielsen KK, Werdelin L. Prevalence of bladder dysfunction in Parkinsons disease. Neurourol Urodyn. 2006;25(2):116-22.

8. Sakakibara R, Uchiyama T, Yamanishi T, Shirai K, Hattori T. Bladder and bowel dysfunction in Parkinson's disease. J Neural Transm. 2008;115(3):443-60.

9. Sakakibara R, Hattori T, Uchiyama T, Yamanishi T. Videourodynamic and sphincter motor unit potential analyses in Parkinson's disease and multiple system atrophy. J Neurol Neurosurg Psychiatry. 2001;71(5):600-6.

10. Tibaek S, Gard G, Klarskov P, Iversen HK, Dehlendorff C, Jensen R. Prevalence of lower urinary tract symptoms (LUTS) in stroke patients: a cross-sectional, clinical survey. Neurourol Urodyn. 2008;27(8):763-71.

11. Gupta A, Taly AB, Srivastava A, Thyloth M. Urodynamics post stroke in patients with urinary incontinence: Is there correlation between bladder type and site of lesion? Ann Indian Acad Neurol. 2009;12(2):104-7.

12. Bloch F, Pichon B, Bonnet AM, Pichon J, Vidailhet M, Roze E, et al. Urodynamic analysis in multiple system atrophy: characterization of detrusor-sphincter dyssynergia. J Neurol. 2010;257(12): 1986-91. 
13. Sakakibara R, Hattori T, Uchiyama T, Kita K, Asahina M, Suzuki A, et al. Urinary dysfunction and orthostatic hypotension in multiple system atrophy: which is the more common and earlier manifestation? J Neurol Neurosurg Psychiatry. 2000;68(1):65-9.

14. Jeong SJ, Cho SY. Oh SJ. Spinal cord/brain injury and the neurogenic bladder. Urol Clin North Am. 2010;37(4):537-46.

15. Zhang L, Zhu L, Xu T, Lang J, Li Z, Gong J, et al. A populationbased survey of the prevalence, potential risk factors, and symptom-specific bother of lower urinary tract symptoms in adult Chinese women. Eur Urol. 2015;68(1):97-112.

16. Irwin DE, Milsom I, Kopp Z, Abrams P, Group ES. Symptom bother and health care-seeking behavior among individuals with overactive bladder. Eur Urol. 2008;53(5):1029-37.

17. Coyne KS, Sexton CC, Irwin DE, Kopp ZS, Kelleher CJ, Milsom I. The impact of overactive bladder, incontinence and other lower urinary tract symptoms on quality of life, work productivity, sexuality and emotional well-being in men and women: results from the EPIC study. BJU Int. 2008;101(11):1388-95.

18. Simpson LA, Eng JJ, Hsieh JT, Wolfe DL, Scire SCIRE. Research T. the health and life priorities of individuals with spinal cord injury: a systematic review. J Neurotrauma. 2012;29(8):1548-55.

19. Abrams P, Cardozo L, Fall M, Griffiths D, Rosier P, Ulmsten U, et al. The standardization of terminology of lower urinary tract function: report from the Standardization Sub-committee of the International Continence Society. Neurourol Urodyn. 2002;21(2):167-78.

20. Steinhardt GF, Goodgold HM, Samuels LD. The effect of intravesical pressure on glomerular filtration rate in patients with myelomeningocele. J Urol. 1988;140(5 Pt 2):1293-5.

21. McGuire EJ, Woodside JR, Borden TA, Weiss RM. Prognostic value of urodynamic testing in myelodysplastic patients. J Urol. 1981;126(2):205-9.

22. Shingleton WB, Bodner DR. The development of urologic complications in relationship to bladder pressure in spinal cord injured patients. J Am Paraplegia Soc. 1993;16(1):14-7.

23. Muller T, Arbeiter $\mathrm{K}$, Aufricht $\mathrm{C}$. Renal function in meningomyelocele: risk factors, chronic renal failure, renal replacement therapy and transplantation. Curr Opin Urol. 2002;12(6):479-84.

24. Siroky MB. Pathogenesis of bacteriuria and infection in the spinal cord injured patient. Am J Med. 2002;113(Suppl 1A):67S-79S.

25. Kroll P, Zachwieja J. Complications of untreated and ineffectively treated neurogenic bladder dysfunctions in children: our own practical classification. Eur Rev Med Pharmacol Sci. 2016;20(7): 1229-37.

26. Veenboer PW, Bosch JL, van Asbeck FW, de Kort LM. Upper and lower urinary tract outcomes in adult myelomeningocele patients: a systematic review. PLoS One 2012;7(10):e48399.

27. Lawrenson R, Wyndaele JJ, Vlachonikolis I, Farmer C, Glickman $\mathrm{S}$. Renal failure in patients with neurogenic lower urinary tract dysfunction. Neuroepidemiology. 2001;20(2):138-43.

28. Game X, Castel-Lacanal E, Bentaleb Y, Thiry-Escudie I, De Boissezon X, Malavaud B, et al. Botulinum toxin A detrusor injections in patients with neurogenic detrusor overactivity significantly decrease the incidence of symptomatic urinary tract infections. Eur Urol. 2008;53(3):613-8.

29. Geisler WO, Jousse AT, Wynne-Jones M, Breithaupt D. Survival in traumatic spinal cord injury. Paraplegia. 1983;21(6):364-73.

30. Hackler RH. A 25-year prospective mortality study in the spinal cord injured patient: comparison with the long-term living paraplegic. J Urol. 1977;117(4):486-8.

31. Frankel HL, Coll JR, Charlifue SW, Whiteneck GG, Gardner BP, Jamous MA, et al. Long-term survival in spinal cord injury: a fifty year investigation. Spinal Cord. 1998;36(4):266-74.
32. Soden RJ, Walsh J, Middleton JW, Craven ML, Rutkowski SB, Yeo JD. Causes of death after spinal cord injury. Spinal Cord. 2000;38(10):604-10.

33. van den Berg ME, Castellote JM, de Pedro-Cuesta J, MahilloFernandez I. Survival after spinal cord injury: a systematic review. J Neurotrauma 2010;27(8):1517-1528.

34. Breithaupt DJ, Jousse AT, Wynn-Jones M. Late causes of death and life expectancy in paraplegia. Can Med Assoc J. 1961;85(2): 73-7.

35. Freed MM, Bakst HJ, Barrie DL. Life expectancy, survival rates, and causes of death in civilian patients with spinal cord trauma. Arch Phys Med Rehabil. 1966;47(7):457-63.

36. Whiteneck GG, Charlifue SW, Frankel HL, Fraser MH, Gardner BP, Gerhart KA, et al. Mortality, morbidity, and psychosocial outcomes of persons spinal cord injured more than 20 years ago. Paraplegia. 1992;30(9):617-30.

37. Louapre C, Papeix C, Lubetzki C, Maillart E. Multiple sclerosis and aging. Geriatr Psychol Neuropsychiatr Vieil. 2017;15(4):4028 .

38. Sanai SA, Saini V, Benedict RH, Zivadinov R, Teter BE, Ramanathan M, et al. Aging and multiple sclerosis. Mult Scler. 2016;22(6):717-25.

39. Veenboer PW, de Kort LM, Chrzan RJ, de Jong TP. Urinary considerations for adult patients with spinal dysraphism. Nat Rev Urol 2015;12(6):331-339.

40. Savic G, DeVivo MJ, Frankel HL, Jamous MA, Soni BM, Charlifue S. Long-term survival after traumatic spinal cord injury: a 70-year British study. Spinal Cord. 2017;55(7):651-8.

41. Abdullah R, Basak I, Patil KS, Alves G, Larsen JP, Moller SG. Parkinson's disease and age: the obvious but largely unexplored link. Exp Gerontol. 2015;68:33-8.

42. Garcia-Ruiz PJ, Espay AJ. Parkinson disease: an evolutionary perspective. Front Neurol. 2017;8:157.

43. Ismail S, Karsenty G, Chartier-Kastler E, Cussenot O, Comperat E, Roupret M, et al. Prevalence, management, and prognosis of bladder cancer in patients with neurogenic bladder: a systematic review. Neurourol Urodyn. 2018;37(4):1386-95.

44. Bothig R, Kurze I, Fiebag K, Kaufmann A, Schops W, Kadhum T, et al. Clinical characteristics of bladder cancer in patients with spinal cord injury: the experience from a single Centre. Int Urol Nephrol. 2017;49(6):983-94.

45. Mirkin K, Casey JT, Mukherjee S, Kielb SJ. Risk of bladder cancer in patients with spina bifida: case reports and review of the literature. J Pediatr Rehabil Med. 2013;6(3):155-62.

46. Gerridzen RG, Thijssen AM, Dehoux E. Risk factors for upper tract deterioration in chronic spinal cord injury patients. J Urol. 1992;147(2):416-8.

47. Esclarin De Ruz A, Garcia Leoni E, Herruzo Cabrera R. Epidemiology and risk factors for urinary tract infection in patients with spinal cord injury. J Urol. 2000;164(4):1285-9.

48. Mehnert U. Chapter 24: management of bladder, bowel, and sexual dysfunction. In: Dietz V, Ward N, editors. Oxford textbook of neurorehabilitation. Oxford: Oxford University Press; 2015. p. 281-313.

49. Stephens FD. Intramural ureter and Ureterocele. Postgrad Med J. 1964;40:179-83.

50. Bruschini H, Almeida FG, Srougi M. Upper and lower urinary tract evaluation of 104 patients with myelomeningocele without adequate urological management. World J Urol. 2006;24(2):2248.

51. Kim YH, Kattan MW, Boone TB. Bladder leak point pressure: the measure for sphincterotomy success in spinal cord injured patients with external detrusor-sphincter dyssynergia. J Urol. 1998;159(2): 493-6 discussion 6-7. 
52. Elmelund M, Klarskov N, Bagi P, Oturai PS, Biering-Sorensen F. Renal deterioration after spinal cord injury is associated with length of detrusor contractions during cystometry-a study with a median of 41 years follow-up. Neurourol Urodyn 2016.

53. Sauerwein D. Urinary tract infection in patients with neurogenic bladder dysfunction. Int J Antimicrob Agents. 2002;19(6):592-7.

54. Stoffel JT. Detrusor sphincter dyssynergia: a review of physiology, diagnosis, and treatment strategies. Transl Androl Urol. 2016;5(1): $127-35$.

55. Abrams P, Cardozo L, Fall M, Griffiths D, Rosier P, Ulmsten U, et al. The standardisation of terminology in lower urinary tract function: report from the standardisation sub-committee of the International Continence Society. Urology. 2003;61(1):37-49.

56. Ahmed HU, Shergill IS, Arya M, Shah PJ. Management of detrusor-external sphincter dyssynergia. Nat Clin Pract Urol. 2006;3(7):368-80.

57. Blaivas JG, Sinha HP, Zayed AA, Labib KB. Detrusor-external sphincter dyssynergia: a detailed electromyographic study. J Urol. 1981;125(4):545-8.

58. Blaivas JG, Sinha HP, Zayed AA, Labib KB. Detrusor-external sphincter dyssynergia. J Urol. 1981;125(4):542-4.

59. Chancellor MB, Kaplan SA, Blaivas JG. Detrusor-external sphincter dyssynergia. CIBA Found Symp. 1990;151:195-206 discussion 7-13.

60. Chen CY, Liao CH, Kuo HC. Therapeutic effects of detrusor botulinum toxin A injection on neurogenic detrusor overactivity in patients with different levels of spinal cord injury and types of detrusor sphincter dyssynergia. Spinal Cord. 2011;49(5):659-64.

61. Blackmer J. Rehabilitation medicine: 1. Autonomic dysreflexia. CMAJ. 2003;169(9):931-5.

62. Wan D, Krassioukov AV. Life-threatening outcomes associated with autonomic dysreflexia: a clinical review. J Spinal Cord Med. 2014;37(1):2-10.

63. Krassioukov A, Biering-Sorensen F, Donovan W, Kennelly M, Kirshblum S, Krogh K, et al. International standards to document remaining autonomic function after spinal cord injury. J Spinal Cord Med. 2012;35(4):201-10.

64. Cragg J, Krassioukov A. Autonomic dysreflexia. CMAJ. 2012;184(1):66.

65. Blok BF, Pannek J, Castro-Diaz D, del Popolo G, Groen J, Hamid R, et al. EAU Guidelines on Neuro-Urology2017. Available from: http://uroweb.org/guideline/neuro-urology/.

66. Andersson KE. Potential future pharmacological treatment of bladder dysfunction. Basic Clin Pharmacol Toxicol. 2016;119(Suppl 3):75-85.

67. Abrams P, Andersson KE, Buccafusco JJ, Chapple C, de Groat WC, Fryer AD, et al. Muscarinic receptors: their distribution and function in body systems, and the implications for treating overactive bladder. Br J Pharmacol. 2006;148(5):565-78.

68. Giglio D, Tobin G. Muscarinic receptor subtypes in the lower urinary tract. Pharmacology. 2009;83(5):259-69.

69. Andersson KE. Antimuscarinics for treatment of overactive bladder. Lancet Neurol. 2004;3(1):46-53.

70. de Groat WC, Griffiths D, Yoshimura N. Neural control of the lower urinary tract. Compr Physiol 2015;5(1):327-396.

71. Stevens LA, Chapple CR, Chess-Williams R. Human idiopathic and neurogenic overactive bladders and the role of M2 muscarinic receptors in contraction. Eur Urol. 2007;52(2):531-8.

72. Datta SN, Roosen A, Pullen A, Popat R, Rosenbaum TP, Elneil S, et al. Immunohistochemical expression of muscarinic receptors in the urothelium and suburothelium of neurogenic and idiopathic overactive human bladders, and changes with botulinum neurotoxin administration. J Urol. 2010;184(6):2578-85.

73. Somogyi GT, de Groat WC. Function, signal transduction mechanisms and plasticity of presynaptic muscarinic receptors in the urinary bladder. Life Sci 1999;64(6-7):411-418.
74. Somogyi GT, Zernova GV, Yoshiyama M, Rocha JN, Smith CP, de Groat WC. Change in muscarinic modulation of transmitter release in the rat urinary bladder after spinal cord injury. Neurochem Int 2003;43(1):73-77.

75. Michel MC. beta-Adrenergic Receptor Subtypes in the Urinary Tract. Handb Exp Pharmacol. 2011(202):307-18.

76. Herschorn S, Barkin J, Castro-Diaz D, Frankel JM, Espuna-Pons $\mathrm{M}$, Gousse AE, et al. A phase III, randomized, double-blind, parallel-group, placebo-controlled, multicentre study to assess the efficacy and safety of the beta(3) adrenoceptor agonist, mirabegron, in patients with symptoms of overactive bladder. Urology. 2013;82(2):313-20.

77. Chapple C, Khullar V, Nitti VW, Frankel J, Herschorn S, Kaper M, et al. Efficacy of the beta3-adrenoceptor agonist mirabegron for the treatment of overactive bladder by severity of incontinence at baseline: a post hoc analysis of pooled data from three randomised phase 3 trials. Eur Urol. 2015;67(1):11-4.

78. Brady CM, Apostolidis A, Yiangou Y, Baecker PA, Ford AP, Freeman A, et al. P2X3-immunoreactive nerve fibres in neurogenic detrusor overactivity and the effect of intravesical resiniferatoxin. Eur Urol. 2004;46(2):247-53.

79. Pannek J, Janek S, Sommerer F, Tannapfel A. Expression of purinergic P2X2-receptors in neurogenic bladder dysfunction due to spinal cord injury: a preliminary immunohistochemical study. Spinal Cord. 2009;47(7):561-4.

80. Apostolidis A, Popat R, Yiangou Y, Cockayne D, Ford AP, Davis $\mathrm{JB}$, et al. Decreased sensory receptors P2X3 and TRPV1 in suburothelial nerve fibers following intradetrusor injections of botulinum toxin for human detrusor overactivity. J Urol. 2005;174(3):977-82 discussion 82-3.

81. Munoz A, Somogyi GT, Boone TB, Ford AP, Smith CP. Modulation of bladder afferent signals in normal and spinal cord-injured rats by purinergic $\mathrm{P} 2 \mathrm{X} 3$ and $\mathrm{P} 2 \mathrm{X} 2 / 3$ receptors. BJU Int. 2012;110(8 Pt B):E409-14.

82. Lu SH, Groat WC, Lin AT, Chen KK, Chang LS. Evaluation of purinergic mechanism for the treatment of voiding dysfunction: a study in conscious spinal cord-injured rats. J Chin Med Assoc. 2007;70(10):439-44.

83. Skryma R, Prevarskaya N, Gkika D, Shuba Y. From urgency to frequency: facts and controversies of TRPs in the lower urinary tract. Nat Rev Urol. 2011;8(11):617-30.

84. Brady CM, Apostolidis AN, Harper M, Yiangou Y, Beckett A, Jacques TS, et al. Parallel changes in bladder suburothelial vanilloid receptor TRPV1 and pan-neuronal marker PGP9.5 immunoreactivity in patients with neurogenic detrusor overactivity after intravesical resiniferatoxin treatment. BJU Int. 2004;93(6): $770-6$.

85. Apostolidis A, Brady CM, Yiangou Y, Davis J, Fowler CJ, Anand P. Capsaicin receptor TRPV1 in urothelium of neurogenic human bladders and effect of intravesical resiniferatoxin. Urology. 2005;65(2):400-5.

86. Phe V, Schneider MP, Peyronnet B, Abo Youssef N, Mordasini L, Chartier-Kastler E, et al. Intravesical vanilloids for treating neurogenic lower urinary tract dysfunction in patients with multiple sclerosis: a systematic review and meta-analysis. A report from the neuro-urology promotion Committee of the International Continence Society (ICS). Neurourol Urodyn. 2018;37(1):67-82.

87. Pacher P, Batkai S, Kunos G. The endocannabinoid system as an emerging target of pharmacotherapy. Pharmacol Rev. 2006;58(3): 389-462.

88. Adhikary S, Li H, Heller J, Skarica M, Zhang M, Ganea D, et al. Modulation of inflammatory responses by a cannabinoid-2selective agonist after spinal cord injury. J Neurotrauma. 2011;28(12):2417-27.

89. Abo Youssef N, Schneider MP, Mordasini L, Ineichen BV, Bachmann LM, Chartier-Kastler E, et al. Cannabinoids for 
treating neurogenic lower urinary tract dysfunction in patients with multiple sclerosis: a systematic review and meta-analysis. BJU Int. 2017;119(4):515-21.

90. Madhuvrata P, Singh M, Hasafa Z, Abdel-Fattah M. Anticholinergic drugs for adult neurogenic detrusor overactivity: a systematic review and meta-analysis. Eur Urol. 2012;62(5): 816-30.

91. Novara G, Galfano A, Secco S, D'Elia C, Cavalleri S, Ficarra V, et al. A systematic review and meta-analysis of randomized controlled trials with antimuscarinic drugs for overactive bladder. Eur Urol. 2008;54(4):740-63.

92. Madersbacher H, Murtz G, Stohrer M. Neurogenic detrusor overactivity in adults: a review on efficacy, tolerability and safety of oral antimuscarinics. Spinal Cord. 2013;51(6):432-41.

93. Wang AC, Chen MC, Kuo WY, Lin YH, Wang YC, Lo TS. Urgency-free time interval as primary endpoint for evaluating the outcome of a randomized OAB treatment. Int Urogynecol J Pelvic Floor Dysfunct. 2009;20(7):819-25.

94. Tanaka Y, Masumori N, Tsukamoto T. Urodynamic effects of solifenacin in untreated female patients with symptomatic overactive bladder. Int J Urol. 2010;17(9):796-800.

95. Karram MM, Toglia MR, Serels SR, Andoh M, Fakhoury A, Forero-Schwanhaeuser S. Treatment with solifenacin increases warning time and improves symptoms of overactive bladder: results from VENUS, a randomized, double-blind, placebocontrolled trial. Urology. 2009;73(1):14-8.

96. Nabi G, Cody JD, Ellis G, Herbison P, Hay-Smith J. Anticholinergic drugs versus placebo for overactive bladder syndrome in adults. Cochrane Database Syst Rev. 2006;4: CD003781.

97. Stahl MM, Ekstrom B, Sparf B, Mattiasson A, Andersson KE. Urodynamic and other effects of tolterodine: a novel antimuscarinic drug for the treatment of detrusor overactivity. Neurourol Urodyn. 1995;14(6):647-55.

98. Rentzhog L, Stanton SL, Cardozo L, Nelson E, Fall M, Abrams P. Efficacy and safety of tolterodine in patients with detrusor instability: a dose-ranging study. Br J Urol. 1998;81(1):42-8.

99. Kessler TM, Bachmann LM, Minder C, Lohrer D, Umbehr M, Schunemann HJ, et al. Adverse event assessment of antimuscarinics for treating overactive bladder: a network metaanalytic approach. PLoS One. 2011;6(2):e16718.

100. Athanasopoulos A. Antimuscarinics and bladder outlet obstruction: from a contraindication to an indication? Neurourol Urodyn. 2010;29(Suppl 1):S46-50.

101. Buser N, Ivic S, Kessler TM, Kessels AG, Bachmann LM. Efficacy and adverse events of antimuscarinics for treating overactive bladder: network meta-analyses. Eur Urol. 2012;62(6): 1040-60.

102. Andersson KE. Antimuscarinic mechanisms and the overactive detrusor: an update. Eur Urol. 2011;59(3):377-86.

103. de Groat WC. A neurologic basis for the overactive bladder. Urology 1997;50(6A Suppl):36-52; discussion 3-6.

104. Yamaguchi O. Antimuscarinics and overactive bladder: other mechanism of action. Neurourol Urodyn. 2010;29(1):112-5.

105. Yokoyama O, Tanaka I, Kusukawa N, Yamauchi H, Ito H, Aoki Y, et al. Antimuscarinics suppress adenosine triphosphate and prostaglandin E2 release from urothelium with potential improvement in detrusor overactivity in rats with cerebral infarction. J Urol. 2011;185(6):2392-7.

106. Gillespie JI. The autonomous bladder: a view of the origin of bladder overactivity and sensory urge. BJU Int. 2004;93(4):47883.

107. Athanasopoulos A. The pharmacotherapy of overactive bladder. Expert Opin Pharmacother. 2011;12(7):1003-5.
108. Madhuvrata P, Cody JD, Ellis G, Herbison GP, Hay-Smith EJ. Which anticholinergic drug for overactive bladder symptoms in adults. Cochrane Database Syst Rev. 2012;1:CD005429.

109. Hadiji N, Previnaire JG, Benbouzid R, Robain G, Leblond C, Mieusset R, et al. Are oxybutynin and trospium efficacious in the treatment of detrusor overactivity in spinal cord injury patients? Spinal Cord. 2014;52(9):701-5.

110. Krebs J, Pannek J. Effects of solifenacin in patients with neurogenic detrusor overactivity as a result of spinal cord lesion. Spinal Cord. 2013;51(4):306-9.

111. Horstmann M, Schaefer T, Aguilar Y, Stenzl A, Sievert KD. Neurogenic bladder treatment by doubling the recommended antimuscarinic dosage. Neurourol Urodyn. 2006;25(5):441-5.

112. Nardulli R, Losavio E, Ranieri M, Fiore P, Megna G, Bellomo RG, et al. Combined antimuscarinics for treatment of neurogenic overactive bladder. Int J Immunopathol Pharmacol. 2012;25(1 Suppl): $35 \mathrm{~S}-41 \mathrm{~S}$.

113. Amend B, Hennenlotter J, Schafer T, Horstmann M, Stenzl A, Sievert KD. Effective treatment of neurogenic detrusor dysfunction by combined high-dosed antimuscarinics without increased side-effects. Eur Urol. 2008;53(5):1021-8.

114. Bennett N, O'Leary M, Patel AS, Xavier M, Erickson JR, Chancellor MB. Can higher doses of oxybutynin improve efficacy in neurogenic bladder? J Urol. 2004;171(2 Pt 1):749-51.

115. Menarini M, Del Popolo G, Di Benedetto P, Haselmann J, Bodeker RH, Schwantes U, et al. Trospium chloride in patients with neurogenic detrusor overactivity: is dose titration of benefit to the patients? Int J Clin Pharmacol Ther. 2006;44(12):623-32.

116. Drake MJ, Chapple C, Esen AA, Athanasiou S, Cambronero J, Mitcheson D, et al. Efficacy and safety of mirabegron add-on therapy to solifenacin in incontinent overactive bladder patients with an inadequate response to initial 4-week Solifenacin monotherapy: a randomised double-blind multicentre phase 3B study (BESIDE). Eur Urol. 2016;70(1):136-45.

117. Abrams P, Kelleher C, Staskin D, Rechberger T, Kay R, Martina $\mathrm{R}$, et al. Combination treatment with mirabegron and solifenacin in patients with overactive bladder: efficacy and safety results from a randomised, double-blind, dose-ranging, phase 2 study (symphony). Eur Urol. 2015;67(3):577-88.

118. Wollner J, Pannek J. Initial experience with the treatment of neurogenic detrusor overactivity with a new beta-3 agonist (mirabegron) in patients with spinal cord injury. Spinal Cord. 2016;54(1):78-82.

119. Krhut J, Borovička V, Bílková K, Sýkora R, Míka D, Mokriš J, Zachoval R. Efficacy and safety of mirabegron for the treatment of neurogenic detrusor overactivity-Prospective, randomized, double-blind, placebo-controlled study. Neurourol Urodyn. 2018;37(7):2226-33.

120. Craggs M, McFarlane J. Neuromodulation of the lower urinary tract. Exp Physiol. 1999;84(1):149-60.

121. Staskin DR, Peters KM, MacDiarmid S, Shore N, de Groat WC. Percutaneous tibial nerve stimulation: a clinically and cost effective addition to the overactive bladder algorithm of care. Curr Urol Rep 2012;13(5):327-334.

122. Melzack R, Wall PD. Pain mechanisms: a new theory. Science. 1965;150(3699):971-9.

123. Lindstrom S, Fall M, Carlsson CA, Erlandson BE. The neurophysiological basis of bladder inhibition in response to intravaginal electrical stimulation. J Urol. 1983;129(2):405-10.

124. Gross T, Schneider MP, Bachmann LM, Blok BF, Groen J, Hoen LA, et al. Transcutaneous electrical nerve stimulation for treating neurogenic lower urinary tract dysfunction: a systematic review. Eur Urol. 2016;69(6):1102-11.

125. Schneider MP, Gross T, Bachmann LM, Blok BF, Castro-Diaz D, Del Popolo G, et al. Tibial nerve stimulation for treating 
neurogenic lower urinary tract dysfunction: a systematic review. Eur Urol. 2015;68(5):859-67.

126. Parker MM, Rose DK. Inhibition of the bladder. Arch Surg. 1937;34(5):828-38.

127. Alexander S, Rowan D. Electrical control of urinary incontinence: a clinical appraisal. Br J Surg. 1970;57(10):766-8.

128. Godec C, Cass AS, Ayala GF. Bladder inhibition with functional electrical stimulation. Urology. 1975;6(6):663-6.

129. Canbaz Kabay S, Kabay S, Mestan E, Cetiner M, Ayas S, Sevim $\mathrm{M}$, et al. Long term sustained therapeutic effects of percutaneous posterior tibial nerve stimulation treatment of neurogenic overactive bladder in multiple sclerosis patients: 12-months results. Neurourol Urodyn. 2017;36(1):104-10.

130. Lapides J, Diokno AC, Silber SJ, Lowe BS. Clean, intermittent self-catheterization in the treatment of urinary tract disease. J Urol. 1972;107(3):458-61.

131. Rognoni C, Tarricone R. Intermittent catheterisation with hydrophilic and non-hydrophilic urinary catheters: systematic literature review and meta-analyses. BMC Urol. 2017;17(1):4.

132. Rognoni C, Tarricone R. Healthcare resource consumption for intermittent urinary catheterisation: cost-effectiveness of hydrophilic catheters and budget impact analyses. BMJ Open. 2017;7(1):e012360.

133. De Ridder D, Vermeulen C, Ketelaer P, Van Poppel H, Baert L. Pelvic floor rehabilitation in multiple sclerosis. Acta Neurol Belg 1999;99(1):61-64.

134. Hagerty JA, Richards I, Kaplan WE. Intravesical electrotherapy for neurogenic bladder dysfunction: a 22-year experience. J Urol. 2007;178(4 Pt 2):1680-3 discussion 3.

135. Decter RM, Snyder P, Rosvanis TK. Transurethral electrical bladder stimulation: initial results. J Urol. 1992;148(2 Pt 2):651-3 discussion 4

136. Janssen DA, Farag F, Heesakkers JP. Urgent-SQ implant in treatment of overactive bladder syndrome: 9-year follow-up study. Neurourol Urodyn. 2013;32(5):472-5.

137. van Breda HMK, Martens FMJ, Tromp J, Heesakkers J. A new implanted posterior tibial nerve stimulator for the treatment of overactive bladder syndrome: 3-month results of a novel therapy at a single center. J Urol 2017;198(1):205-210.

138. Heesakkers J, Digesu GA, van Breda J, Van Kerrebroeck P, Elneil S. A novel leadless, miniature implantable tibial nerve neuromodulation system for the management of overactive bladder complaints. Neurourol Urodyn 2018;37(3):1060-1067.

139. van der Pal F, van Balken MR, Heesakkers JP, Debruyne FM, Bemelmans BL. Implant-driven tibial nerve stimulation in the treatment of refractory overactive bladder syndrome: 12-month follow-up. Neuromodulation 2006;9(2):163-171.

140. Kessler TM, La Framboise D, Trelle S, Fowler CJ, Kiss G, Pannek $\mathrm{J}$, et al. Sacral neuromodulation for neurogenic lower urinary tract dysfunction: systematic review and meta-analysis. Eur Urol. 2010;58(6):865-74.

141. Apostolidis A. Neuromodulation for intractable OAB. Neurourol Urodyn. 2011;30(5):766-70.

142. Van Kerrebroeck PE. Advances in the role of sacral nerve neuromodulation in lower urinary tract symptoms. Int Urogynecol J 2010;21 Suppl 2:S467-S474.

143. Kessler TM, Fowler CJ. Sacral neuromodulation for urinary retention. Nat Clin Pract Urol. 2008;5(12):657-66.

144. Schurch B, Reilly I, Reitz A, Curt A. Electrophysiological recordings during the peripheral nerve evaluation (PNE) test in complete spinal cord injury patients. World J Urol. 2003;20(6):319-22.

145. Wollner J, Hampel C, Kessler TM. Surgery illustrated - surgical atlas sacral neuromodulation. BJU Int. 2012;110(1):146-59.

146. Matzel KE, Chartier-Kastler E, Knowles CH, Lehur PA, MunozDuyos A, Ratto C, et al. Sacral neuromodulation: standardized electrode placement technique. Neuromodulation. 2017;20(8): 816-24.

147. Peters KM, Killinger KA, Boura JA. Is sensory testing during lead placement crucial for achieving positive outcomes after sacral neuromodulation? Neurourol Urodyn. 2011;30(8):1489-92.

148. Knupfer SC, Liechti MD, Mordasini L, Abt D, Engeler DS, Wollner J, et al. Protocol for a randomized, placebo-controlled, double-blind clinical trial investigating sacral neuromodulation for neurogenic lower urinary tract dysfunction. BMC Urol. 2014;14:65.

149. Sievert KD, Amend B, Gakis G, Toomey P, Badke A, Kaps HP, et al. Early sacral neuromodulation prevents urinary incontinence after complete spinal cord injury. Ann Neurol. 2010;67(1):74-84.

150. Blok B, Van Kerrebroeck P, de Wachter S, Ruffion A, Van der Aa F, Jairam R, et al. Programming settings and recharge interval in a prospective study of a rechargeable sacral neuromodulation system for the treatment of overactive bladder. Neurourol Urodyn. 2018;37(S2):S17-22.

151. Blok B, Van Kerrebroeck P, de Wachter S, Ruffion A, Van der Aa F, Jairam R, et al. Three month clinical results with a rechargeable sacral neuromodulation system for the treatment of overactive bladder. Neurourol Urodyn. 2018;37(S2):S9-S16.

152. Noblett KL, Dmochowski RR, Vasavada SP, Garner AM, Liu S, Pietzsch JB. Cost profiles and budget impact of rechargeable versus non-rechargeable sacral neuromodulation devices in the treatment of overactive bladder syndrome. Neurourol Urodyn. 2017;36(3):727-33.

153. Jabbari B. History of botulinum toxin treatment in movement disorders. Tremor Other Hyperkinet Mov (N Y). 2016;6:394.

154. Lam SM. The basic science of botulinum toxin. Facial Plast Surg Clin North Am. 2003;11(4):431-8.

155. Pirazzini M, Rossetto O, Eleopra R, Montecucco C. Botulinum neurotoxins: biology, pharmacology, and toxicology. Pharmacol Rev. 2017;69(2):200-35.

156. Karsenty G, Denys P, Amarenco G, De Seze M, Game X, Haab F, et al. Botulinum toxin A (Botox) intradetrusor injections in adults with neurogenic detrusor overactivity/neurogenic overactive bladder: a systematic literature review. Eur Urol. 2008;53(2):275-87.

157. Wollner J, Kessler TM. Botulinum toxin injections into the detrusor. BJU Int. 2011;108(9):1528-37.

158. FDA. Prescribing information for BOTOX (onabotulinumtoxinA) for injection, for intramuscular, intradetrusor, or intradermal use. U.S. Food and Drug Administration, 2011 Available from: https:// www.accessdata.fda.gov/drugsatfda docs/label/2011/ 103000s5232lbl.pdf.

159. Cruz F, Herschorn S, Aliotta P, Brin M, Thompson C, Lam W, et al. Efficacy and safety of onabotulinumtoxinA in patients with urinary incontinence due to neurogenic detrusor overactivity: a randomised, double-blind, placebo-controlled trial. Eur Urol. 2011;60(4):742-50.

160. Cheng T, Shuang WB, Jia DD, Zhang M, Tong XN, Yang WD, et al. Efficacy and safety of onabotulinumtoxin $\mathrm{A}$ in patients with neurogenic detrusor overactivity: a systematic review and metaanalysis of randomized controlled trials. PLoS One. 2016;11(7): e0159307.

161. Mehnert U, Birzele J, Reuter K, Schurch B. The effect of botulinum toxin type a on overactive bladder symptoms in patients with multiple sclerosis: a pilot study. J Urol. 2010;184(3):1011-6.

162. Del Popolo G, Filocamo MT, Li Marzi V, Macchiarella A, Cecconi F, Lombardi G, et al. Neurogenic detrusor overactivity treated with english botulinum toxin a: 8-year experience of one single Centre. Eur Urol. 2008;53(5):1013-9.

163. Grosse J, Kramer G, Stohrer M. Success of repeat detrusor injections of botulinum a toxin in patients with severe neurogenic detrusor overactivity and incontinence. Eur Urol. 2005;47(5): $653-9$. 
164. Karsenty G, Reitz A, Lindemann G, Boy S, Schurch B. Persistence of therapeutic effect after repeated injections of botulinum toxin type A to treat incontinence due to neurogenic detrusor overactivity. Urology. 2006;68(6):1193-7.

165. Apostolidis A, Rahnama'i MS, Fry C, Dmochowski R, Sahai A. Do we understand how botulinum toxin works and have we optimized the way it is administered to the bladder? ICI-RS 2014. Neurourol Urodyn. 2016;35(2):293-8.

166. Maria G, Brisinda G, Civello IM, Bentivoglio AR, Sganga G, Albanese A. Relief by botulinum toxin of voiding dysfunction due to benign prostatic hyperplasia: results of a randomized, placebo-controlled study. Urology. 2003;62(2):259-64 discussion 64-5.

167. Boy S, Reitz A, Curt A, Schurch B. A case of undiagnosed tethered cord syndrome aggravated by transurethral prostate resection. Nat Clin Pract Urol. 2005;2(4):199-204 quiz 1 p following.

168. Bruschini H, Simonetti R, Antunes AA, Srougi M. Urinary incontinence following surgery for BPH: the role of aging on the incidence of bladder dysfunction. Int Braz J Urol. 2011;37(3):380-6 discussion 7.

169. Theodorou C, Moutzouris G, Floratos D, Plastiras D, Katsifotis C, Mertziotis N. Incontinence after surgery for benign prostatic hypertrophy: the case for complex approach and treatment. Eur Urol. 1998;33(4):370-5.

170. Kutzenberger J. Surgical therapy of neurogenic detrusor overactivity (hyperreflexia) in paraplegic patients by sacral deafferentation and implant driven micturition by sacral anterior root stimulation: methods, indications, results, complications, and future prospects. Acta Neurochir Suppl. 2007;97(Pt 1):333-9.

171. Seif C, Junemann KP, Braun PM. Deafferentation of the urinary bladder and implantation of a sacral anterior root stimulator (SARS) for treatment of the neurogenic bladder in paraplegic patients. Biomed Tech (Berl). 2004;49(4):88-92.

172. Krasmik D, Krebs J, van Ophoven A, Pannek J. Urodynamic results, clinical efficacy, and complication rates of sacral intradural deafferentation and sacral anterior root stimulation in patients with neurogenic lower urinary tract dysfunction resulting from complete spinal cord injury. Neurourol Urodyn 2014;33(8):12021206.

173. Van Kerrebroeck PE, Koldewijn EL, Debruyne FM. Worldwide experience with the Finetech-Brindley sacral anterior root stimulator. Neurourol Urodyn 1993;12(5):497-503.

174. Karsenty G, Chartier-Kastler E, Mozer P, Even-Schneider A, Denys P, Richard F. A novel technique to achieve cutaneous continent urinary diversion in spinal cord-injured patients unable to catheterize through native urethra. Spinal Cord. 2008;46(4):30510.

175. Greenwell TJ, Venn SN, Mundy AR. Augmentation cystoplasty. BJU Int. 2001;88(6):511-25.

176. Blaivas JG, Weiss JP, Desai P, Flisser AJ, Stember DS, Stahl PJ. Long-term followup of augmentation enterocystoplasty and continent diversion in patients with benign disease. J Urol. 2005;173(5):1631-4

177. Chartier-Kastler EJ, Mongiat-Artus P, Bitker MO, Chancellor MB, Richard F, Denys P. Long-term results of augmentation cystoplasty in spinal cord injury patients. Spinal Cord. 2000;38(8):490-4.

178. Flood HD, Malhotra SJ, O'Connell HE, Ritchey MJ, Bloom DA, McGuire EJ. Long-term results and complications using augmentation cystoplasty in reconstructive urology. Neurourol Urodyn. 1995;14(4):297-309.

179. Lima SV, Araujo LA, Vilar Fde O, Lima RS, Lima RF. Nonsecretory intestinocystoplasty: a 15-year prospective study of 183 patients. J Urol. 2008;179(3):1113-6 discussion 6-7.

180. Venn SN, Mundy AR. Long-term results of augmentation cystoplasty. Eur Urol. 1998;34(Suppl 1):40-2.
181. Juhasz Z, Somogyi R, Vajda P, Oberritter Z, Fathi K, Pinter AB. Does the type of bladder augmentation influence the resolution of pre-existing vesicoureteral reflux? Urodynamic studies. Neurourol Urodyn. 2008;27(5):412-6.

182. Herschorn S, Hewitt RJ. Patient perspective of long-term outcome of augmentation cystoplasty for neurogenic bladder. Urology. 1998;52(4):672-8.

183. Mills RD, Studer UE. Metabolic consequences of continent urinary diversion. J Urol. 1999;161(4):1057-66.

184. Sahadevan K, Pickard RS, Neal DE, Hasan TS. Is continent diversion using the Mitrofanoff principle a viable long-term option for adults requiring bladder replacement? BJU Int. 2008;102(2): 236-40.

185. Thomas JC, Dietrich MS, Trusler L, DeMarco RT, Pope JC, Brock JW 3rd, et al. Continent catheterizable channels and the timing of their complications. J Urol. 2006;176(4 Pt 2):1816-20 discussion 20.

186. Welk BK, Afshar K, Rapoport D, MacNeily AE. Complications of the catheterizable channel following continent urinary diversion: their nature and timing. J Urol. 2008;180(4 Suppl):1856-60.

187. Fisch M, Thuroff JW. Continent cutaneous diversion. BJU Int 2008;102(9 Pt B):1314-9.

188. Hautmann RE. Urinary diversion: ileal conduit to neobladder. J Urol. 2003;169(3):834-42.

189. Bricker EM. Bladder substitution after pelvic evisceration. Surg Clin North Am. 1950;30(5):1511-21.

190. Madersbacher S, Schmidt J, Eberle JM, Thoeny HC, Burkhard F, Hochreiter W, et al. Long-term outcome of ileal conduit diversion. J Urol. 2003;169(3):985-90.

191. Pagano S, Ruggeri P, Rovellini P, Bottanelli A. The anterior ileal conduit: results of 100 consecutive cases. J Urol. 2005;174(3): 959-62 discussion 62.

192. Hollingsworth JM, Rogers MA, Krein SL, Hickner A, Kuhn L, Cheng A, et al. Determining the noninfectious complications of indwelling urethral catheters: a systematic review and meta-analysis. Ann Intern Med. 2013;159(6):401-10.

193. Ho CH, Sung KC, Lim SW, Liao CH, Liang FW, Wang JJ, et al. Chronic indwelling urinary catheter increase the risk of bladder cancer, even in patients without spinal cord injury. Medicine (Baltimore). 2015;94(43):e1736.

194. Timoney AG, Shaw PJ. Urological outcome in female patients with spinal cord injury: the effectiveness of intermittent catheterisation. Paraplegia. 1990;28(9):556-63.

195. Jamil F, Williamson M, Ahmed YS, Harrison SC. Natural-fill urodynamics in chronically catheterized patients with spinal-cord injury. BJU Int. 1999;83(4):396-9.

196. Kristiansen P, Pompeius R, Wadström LB. Long-term urethral catheter drainage and bladder capacity. Neurourol Urodyn. 1983;2(2):135-43.

197. Utomo E, Groen J, Blok BF. Surgical management of functional bladder outlet obstruction in adults with neurogenic bladder dysfunction. Cochrane Database Syst Rev. 2014;5:CD004927.

198. Melotti IG, Juliato CR, Tanaka M, Riccetto CL. Severe depression and anxiety in women with overactive bladder. Neurourol Urodyn. 2017.

199. Coyne KS, Wein AJ, Tubaro A, Sexton CC, Thompson CL, Kopp ZS, et al. The burden of lower urinary tract symptoms: evaluating the effect of LUTS on health-related quality of life, anxiety and depression: EpiLUTS. BJU Int. 2009;103(Suppl 3):4-11.

200. Temml C, Haidinger G, Schmidbauer J, Schatzl G, Madersbacher $\mathrm{S}$. Urinary incontinence in both sexes: prevalence rates and impact on quality of life and sexual life. Neurourol Urodyn. 2000;19(3): 259-71.

201. Holroyd S. Incontinence-associated dermatitis: identification, prevention and care. Br J Nurs. 2015;24(9):S37-8 S40-3. 
202. Kim S, Ward E, Dicianno BE, Clayton GH, Sawin KJ, Beierwaltes $\mathrm{P}$, et al. Factors associated with pressure ulcers in individuals with spina bifida. Arch Phys Med Rehabil. 2015;96(8):1435-41 e1.

203. Beeckman D. A decade of research on incontinence-associated dermatitis (IAD): evidence, knowledge gaps and next steps. J Tissue Viability. 2017;26(1):47-56.

204. Ruffion A, Castro-Diaz D, Patel H, Khalaf K, Onyenwenyi A, Globe D, et al. Systematic review of the epidemiology of urinary incontinence and detrusor overactivity among patients with neurogenic overactive bladder. Neuroepidemiology. 2013;41(3-4): $146-55$.

205. Newman DK, Wein AJ. Office-based behavioral therapy for management of incontinence and other pelvic disorders. Urol Clin North Am. 2013;40(4):613-35.

206. Salle JL, McLorie GA, Bagli DJ, Khoury AE. Urethral lengthening with anterior bladder wall flap (Pippi Salle procedure): modifications and extended indications of the technique. J Urol. 1997;158(2):585-90.

207. Donnahoo KK, Rink RC, Cain MP, Casale AJ. The Young-DeesLeadbetter bladder neck repair for neurogenic incontinence. $\mathrm{J}$ Urol. 1999;161(6): 1946-9.

208. Kropp KA, Angwafo FF. Urethral lengthening and reimplantation for neurogenic incontinence in children. J Urol. 1986;135(3):5336.

209. Waters PR, Chehade NC, Kropp KA. Urethral lengthening and reimplantation: incidence and management of catheterization problems. J Urol. 1997;158(3 Pt 2):1053-6.

210. Rink RC, Adams MC, Keating MA. The flip-flap technique to lengthen the urethra (Salle procedure) for treatment of neurogenic urinary incontinence. J Urol. 1994;152(2 Pt 2):799-802.

211. Salle JL, McLorie GA, Bagli DJ, Khoury AE. Modifications of and extended indications for the Pippi Salle procedure. World J Urol. 1998;16(4):279-84.

212. Ferrer FA, Tadros YE, Gearhart J. Modified Young-DeesLeadbetter bladder neck reconstruction: new concepts about old ideas. Urology. 2001;58(5):791-6.

213. Jones JA, Mitchell ME, Rink RC. Improved results using a modification of the young-Dees-Leadbetter bladder neck repair. Br J Urol. 1993;71(5):555-61.

214. Mouriquand PD, Sheard R, Phillips N, White J, Sharma S, Vandeberg C. The Kropp-onlay procedure (Pippi Salle procedure): a simplification of the technique of urethral lengthening. Preliminary results in eight patients. Br J Urol. 1995;75(5):65662.

215. Szymanski KM, Rink RC, Whittam B, Ring JD, Misseri R, Kaefer $\mathrm{M}$, et al. Long-term outcomes of the Kropp and Salle urethral lengthening bladder neck reconstruction procedures. J Pediatr Urol. 2016;12(6):-403 e1- e7.

216. Nakamura S, Hyuga T, Kawai S, Nakai H. Long-term outcome of the Pippi Salle procedure for intractable urinary incontinence in patients with severe intrinsic urethral sphincter deficiency. J Urol. 2015;194(5):1402-6.

217. Mansi M, Ahmed S. Young-Dees-Leadbetter bladder neck reconstruction for sphincteric urinary incontinence: the value of augmentation cystoplasty. Scand J Urol Nephrol. 1993;27(4):509-17.

218. Sidi AA, Reinberg Y, Gonzalez R. Comparison of artificial sphincter implantation and bladder neck reconstruction in patients with neurogenic urinary incontinence. J Urol. 1987;138(4 Pt 2):1120 2.

219. Ghoniem G, Corcos J, Comiter C, Bernhard P, Westney OL, Herschorn S. Cross-linked polydimethylsiloxane injection for female stress urinary incontinence: results of a multicenter, randomized, controlled, single-blind study. J Urol. 2009;181(1):204-10.

220. Ghoniem G, Corcos J, Comiter C, Westney OL, Herschorn S. Durability of urethral bulking agent injection for female stress urinary incontinence: 2-year multicenter study results. J Urol. 2010;183(4):1444-9.

221. Kirchin V, Page T, Keegan PE, Atiemo K, Cody JD, McClinton S. Urethral injection therapy for urinary incontinence in women. Cochrane Database Syst Rev. 2012;2:CD003881.

222. Block CA, Cooper CS, Hawtrey CE. Long-term efficacy of periurethral collagen injection for the treatment of urinary incontinence secondary to myelomeningocele. J Urol. 2003;169(1): $327-9$.

223. Latthe PM. Review of transobturator and retropubic tape procedures for stress urinary incontinence. Curr Opin Obstet Gynecol. 2008;20(4):331-6.

224. Nilsson CG, Palva K, Rezapour M, Falconer C. Eleven years prospective follow-up of the tension-free vaginal tape procedure for treatment of stress urinary incontinence. Int Urogynecol J Pelvic Floor Dysfunct. 2008;19(8):1043-7.

225. Romano SV, Metrebian SE, Vaz F, Muller V, D'Ancona CA, Costa DESEA, et al. An adjustable male sling for treating urinary incontinence after prostatectomy: a phase III multicentre trial. BJU Int 2006;97(3):533-9.

226. Sandhu JS. Treatment options for male stress urinary incontinence. Nat Rev Urol. 2010;7(4):222-8.

227. Snodgrass W, Keefover-Hicks A, Prieto J, Bush N, Adams R. Comparing outcomes of slings with versus without enterocystoplasty for neurogenic urinary incontinence. J Urol. 2009;181(6):2709-14 discussion 14-6.

228. Austin PF, Westney OL, Leng WW, McGuire EJ, Ritchey ML. Advantages of rectus fascial slings for urinary incontinence in children with neuropathic bladders. J Urol. 2001;165(6 Pt 2): 2369-71 discussion 71-2.

229. Castellan M, Gosalbez R, Labbie A, Ibrahim E, Disandro M. Bladder neck sling for treatment of neurogenic incontinence in children with augmentation cystoplasty: long-term followup. J Urol. 2005;173(6):2128-31 discussion 31.

230. Daneshmand S, Ginsberg DA, Bennet JK, Foote J, Killorin W, Rozas KP, et al. Puboprostatic sling repair for treatment of urethral incompetence in adult neurogenic incontinence. J Urol. 2003;169(1):199-202.

231. Mingin GC, Youngren K, Stock JA, Hanna MK. The rectus myofascial wrap in the management of urethral sphincter incompetence. BJU Int. 2002;90(6):550-3.

232. Herschorn S, Radomski SB. Fascial slings and bladder neck tapering in the treatment of male neurogenic incontinence. J Urol. 1992;147(4):1073-5.

233. Chrzan R, Dik P, Klijn AJ, de Jong TP. Sling suspension of the bladder neck for pediatric urinary incontinence. J Pediatr Urol 2009;5(2):82-86.

234. Dik P, Klijn AJ, van Gool JD, de Jong TP. Transvaginal sling suspension of bladder neck in female patients with neurogenic sphincter incontinence. J Urol 2003;170(2 Pt 1):580-581; discussion 1-2.

235. Snodgrass WT, Elmore J, Adams R. Bladder neck sling and appendicovesicostomy without augmentation for neurogenic incontinence in children. J Urol. 2007;177(4):1510-4 discussion 5.

236. Athanasopoulos A, Gyftopoulos K, McGuire EJ. Treating stress urinary incontinence in female patients with neuropathic bladder: the value of the autologous fascia rectus sling. Int Urol Nephrol. 2012;44(5):1363-7.

237. Kakizaki H, Shibata T, Shinno Y, Kobayashi S, Matsumura K, Koyanagi T. Fascial sling for the management of urinary incontinence due to sphincter incompetence. J Urol. 1995;153(3 Pt 1): 644-7.

238. Abdul-Rahman A, Attar KH, Hamid R, Shah PJ. Long-term outcome of tension-free vaginal tape for treating stress incontinence in women with neuropathic bladders. BJU Int. 2010;106(6):82730 . 
239. Losco GS, Burki JR, Omar YA, Shah PJ, Hamid R. Long-term outcome of transobturator tape (TOT) for treatment of stress urinary incontinence in females with neuropathic bladders. Spinal Cord. 2015;53(7):544-6.

240. Groen LA, Spinoit AF, Hoebeke P, Van Laecke E, De Troyer B, Everaert K. The AdVance male sling as a minimally invasive treatment for intrinsic sphincter deficiency in patients with neurogenic bladder sphincter dysfunction: a pilot study. Neurourol Urodyn 2012;31(8):1284-1287.

241. Janknegt RA, Baeten CG, Weil EH, Spaans F. Electrically stimulated gracilis sphincter for treatment of bladder sphincter incontinence. Lancet. 1992;340(8828):1129-30.

242. Williams NS, Fowler CG, George BD, Blandy JP, Badenoch DF, Patel J. Electrically stimulated gracilis sphincter for bladder incontinence. Lancet. 1993;341(8837):115-6.

243. Chancellor MB, Hong RD, Rivas DA, Watanabe T, Crewalk JA, Bourgeois I. Gracilis urethromyoplasty-an autologous urinary sphincter for neurologically impaired patients with stress incontinence. Spinal Cord. 1997;35(8):546-9.

244. Chancellor MB, Heesakkers JP, Janknegt RA. Gracilis muscle transposition with electrical stimulation for sphincteric incontinence: a new approach. World J Urol. 1997;15(5):320-8.

245. Hussain M, Greenwell TJ, Venn SN, Mundy AR. The current role of the artificial urinary sphincter for the treatment of urinary incontinence. J Urol. 2005;174(2):418-24.

246. Fulford SC, Sutton C, Bales G, Hickling M, Stephenson TP. The fate of the 'modern' artificial urinary sphincter with a follow-up of more than 10 years. Br J Urol. 1997;79(5):713-6.

247. Lopez Pereira P, Somoza Ariba I, Martinez Urrutia MJ, Lobato Romero R, Jaureguizar ME. Artificial urinary sphincter: 11-year experience in adolescents with congenital neuropathic bladder. Eur Urol. 2006;50(5):1096-101 discussion 101.

248. Murphy S, Rea D, O'Mahony J, McDermott TE, Thornhill J, Butler M, et al. A comparison of the functional durability of the AMS 800 artificial urinary sphincter between cases with and without an underlying neurogenic aetiology. Ir J Med Sci. 2003;172(3):136-8.

249. Patki P, Hamid R, Shah PJ, Craggs M. Long-term efficacy of AMS 800 artificial urinary sphincter in male patients with urodynamic stress incontinence due to spinal cord lesion. Spinal Cord. 2006;44(5):297-300

250. Simeoni J, Guys JM, Mollard P, Buzelin JM, Moscovici J, Bondonny JM, et al. Artificial urinary sphincter implantation for neurogenic bladder: a multi-institutional study in 107 children. $\mathrm{Br}$ J Urol. 1996;78(2):287-93.
251. Singh G, Thomas DG. Artificial urinary sphincter in patients with neurogenic bladder dysfunction. Br J Urol. 1996;77(2):252-5.

252. Venn SN, Greenwell TJ, Mundy AR. The long-term outcome of artificial urinary sphincters. J Urol. 2000;164(3 Pt 1):702-6 discussion 6-7.

253. Chartier Kastler E, Genevois S, Game X, Denys P, Richard F, Leriche A, et al. Treatment of neurogenic male urinary incontinence related to intrinsic sphincter insufficiency with an artificial urinary sphincter: a French retrospective multicentre study. BJU Int. 2011;107(3):426-32.

254. Bersch U, Gocking K, Pannek J. The artificial urinary sphincter in patients with spinal cord lesion: description of a modified technique and clinical results. Eur Urol. 2009;55(3):687-93.

255. Viers BR, Elliott DS, Kramer SA. Simultaneous augmentation cystoplasty and cuff only artificial urinary sphincter in children and young adults with neurogenic urinary incontinence. J Urol. 2014;191(4):1104-8.

256. Gilling PJ, Bell DF, Wilson LC, Westenberg AM, Reuther R, Fraundorfer MR. An adjustable continence therapy device for treating incontinence after prostatectomy: a minimum 2-year follow-up. BJU Int. 2008;102(10):1426-30 discussion 30-1.

257. Hubner WA, Schlarp OM. Adjustable continence therapy (ProACT): evolution of the surgical technique and comparison of the original 50 patients with the most recent 50 patients at a single Centre. Eur Urol. 2007;52(3):680-6.

258. Mehnert U, Bastien L, Denys P, Cardot V, Even-Schneider A, Kocer $\mathrm{S}$, et al. Treatment of neurogenic stress urinary incontinence using an adjustable continence device: 4-year followup. J Urol. 2012;188(6):2274-80. https://doi.org/10.1016/j.juro.2012.07.131.

259. Ammirati E, Manassero A, Giammò A, Carone R. Management of male and female neurogenic stress urinary incontinence in spinal cord injured (SCI) patients using adjustable continence therapy. Urologia. 2017;184(3):165-8. https://doi.org/10.5301/uj.5000242.

260. Aboseif SR, Franke EI, Nash SD, Slutsky JN, Baum NH, Tu le M, et al. The adjustable continence therapy system for recurrent female stress urinary incontinence: 1-year results of the North America Clinical Study Group. J Urol. 2009;181(5):2187-91. https://doi.org/10.1016/j.juro.2009.01.039.

261. Gregori A, Romanò AL, Scieri F, Pietrantuono F, Incarbone GP, Salvaggio A, et al. Transrectal ultrasound-guided implantation of Adjustable Continence Therapy (ProACT): surgical technique and clinical results after a mean follow-up of 2 years. Eur Urol. 2010;57(3):430-6. https://doi.org/10.1016/j.eururo.2009.11.031. 